\title{
Uniform "water" content in quartz phenocrysts from silicic pyroclastic fallout deposits - implications on pre-eruptive conditions
}

\author{
Mátyás Hencz ${ }^{1}$, Tamás Biróo ${ }^{1}$, István János Kovács ${ }^{2}$, Roland Stalder ${ }^{3}$, Károly Németh ${ }^{4,5}$, \\ Alexandru Szakács ${ }^{6}, Z_{\text {Zsófia Pálos }}{ }^{7}$, Zoltán Pécskay ${ }^{8}$, and Dávid Karátson ${ }^{1}$ \\ ${ }^{1}$ ELTE Eötvös Loránd University, Institute of Geography and Earth Sciences, Department of Physical \\ Geography, Pázmány Péter sétány 1/C, 1117, Budapest, Hungary \\ ${ }^{2}$ MTA EK Lendület Pannon $\mathrm{LitH}_{2}$ Oscope Research Group, \\ Konkoly-Thege Miklós út 29-33, 1121, Budapest, Hungary \\ ${ }^{3}$ Institute of Mineralogy and Petrography, University of Innsbruck, Innrain 52f, 6020, Innsbruck, Austria \\ ${ }^{4}$ School of Agriculture and Environment, Massey University, Private Bag 11, \\ 222 Palmerston North, 4442, New Zealand \\ ${ }^{5}$ Institute of Earth Physics and Space Sciences, Csatkai E. u. 6-8, Sopron, 9400, Hungary \\ ${ }^{6}$ Department of Endogene Processes, Natural Hazard and Risk, Romanian Academy, Institute of Geodynamics, \\ 19-21 Jean-Louis Calderon St., 020032, Bucharest-37, Romania \\ ${ }^{7}$ Department of Earth Sciences, Mineral Resources and Geofluids Group, University of Geneva, \\ 13, Rue des Maraîchers, 1205 Geneva, Switzerland \\ ${ }^{8}$ Institute of Nuclear Research (ATOMKI), Isotope Climatology and Environmental Research Centre (ICER), \\ K-Ar Group, Bem tér 18/c, 4026, Debrecen, Hungary \\ Correspondence: Mátyás Hencz (hemuabt@ staff.elte.hu)
}

Received: 4 May 2021 - Revised: 22 August 2021 - Accepted: 1 September 2021 - Published: 24 September 2021

\begin{abstract}
Structural hydroxyl content of volcanic quartz phenocrysts was investigated with unpolarized Fouriertransform infrared spectroscopy. The phenocrysts originated from five pyroclastic fallout deposits from the Bükk Foreland Volcanic Area (BFVA), Hungary, and two from the AD 1314 Kaharoa eruption (KH eruption), Okataina Volcanic Complex (Taupo Volcanic Zone), New Zealand. All investigated quartz populations contain structural hydroxyl content in a narrow range with an average of $9.3( \pm 1.7) \mathrm{wt} \mathrm{ppm}$. The earlier correlated horizons in the BFVA had the same average structural hydroxyl content (within uncertainty). Thus, it can be concluded that the structural hydroxyl content does not depend on the geographical distance of outcrops of the same units or the temperature or type of the covering deposit. The rare outlier values and similar structural hydroxyl contents show that the fallout horizons cooled fast enough to retain their original structural hydroxyl content. The similarity of the structural hydroxyl contents may be the result of similar $P, T$, and $x$ (most importantly $\mathrm{H}_{2} \mathrm{O}$ and the availability of other monovalent cations) conditions in the magmatic plumbing system just before eruption. Therefore, we envisage common physical-chemical conditions, which set the structural hydroxyl content in the quartz phenocrysts and, consequently, the water content of the host magma $\left(\sim 5.5 \mathrm{wt} \%-7 \mathrm{wt} \% \mathrm{H}_{2} \mathrm{O}\right)$ in a relatively narrow range close to water saturation.
\end{abstract}




\section{Introduction}

Water content significantly affects the physical properties (density, viscosity) of magma and has a large impact on the magnitude and type of the volcanic eruptions especially by moderating explosivity (Sparks, 1978; Dixon and Stolper, 1995; Dingwell, 1996; Popa et al., 2019, 2020, 2021; Allabar et al., 2020). Therefore, it is important to find proxies which allow estimation of the original water content of the magma, and for this reason, investigation of the water content of nominally anhydrous minerals (NAMs hereafter) has come to the forefront of this research. For estimating the original magmatic water content, the commonly used NAMs are clinopyroxene (Weis et al., 2015; Lloyd et al., 2016; Turner et al., 2017), olivine (Portnyagin et al., 2008; Kovács et al., 2010; Barth et al., 2019) and plagioclase (Johnson and Rossman, 2003, 2013; Johnson, 2006; Hamada et al., 2011, 2013).

Quartz is one of the most abundant minerals in the Earth's continental crust and occurs very often in the most differentiated, silicic magmatic rocks (Ronov and Yaroshevski, 1969). Hence, for calculation of magmatic water content quartz can be a good candidate due to its abundance and resistivity against environmental alteration factors (i.e., weathering). Quartz is nominally anhydrous but incorporates certain amounts of OH by coupled substitutions (Kats, 1962; Müller and Koch-Müller, 2009; Stalder and Konzett, 2012; Frigo et al., 2016; Biró et al., 2016, 2017; Jollands et al., 2020a). An effective method to determine the structural hydroxyl content of NAMs is micro-Fourier transform infrared (FTIR hereafter) due to its sensitivity to the hydroxyl vibrations in minerals. It is a cost-effective method with a relatively simple preparation procedure compared to that of melt inclusion studies. FTIR spectra of quartz have been studied for decades (e.g., Kats, 1962), and the incorporation of trace species (most importantly $\mathrm{H}^{+}$) is well-established: the most common heterovalent substitution in quartz is $\mathrm{Si}^{4+} \leftarrow \mathrm{Al}^{3+}+\mathrm{H}^{+}$, which results in $\mathrm{AlOH}$ defects causing three characteristic absorption bands at 3310,3378 , and $3430 \mathrm{~cm}^{-1}$, respectively in the FTIR spectra (Kats, 1962; Stalder and Konzett, 2012; Frigo et al., 2016; Biró et al., 2017; Jollands et al., 2020a). In the case of Li-bearing systems, a sharp band occurs at $3483 \mathrm{~cm}^{-1}$, which is caused by LiOH defects (Frigo et al., 2016), and commonly appears in the absorption spectra of volcanic quartz phenocrysts (Biró et al., 2017; Jollands et al., 2020a). A broad and weak absorption band can occur between $\sim 3480$ and $3100 \mathrm{~cm}^{-1}$, centered at $3400 \mathrm{~cm}^{-1}$, which is usually interpreted as molecular $\mathrm{H}_{2} \mathrm{O}$ present in (nano)inclusions (Aines and Rossman, 1984; Stenina, 2004; Biró et al., 2016). Another subordinated incorporation mechanism of $\mathrm{H}+$ is evidenced by a band centered at $3585 \mathrm{~cm}^{-1}$ corresponding to weakly H-bonded silanol groups in pure quartz (Stalder and Konzett, 2012). In addition, a characteristic peak (centered at $\sim 3200 \mathrm{~cm}^{-1}$ ) may represent more strongly bonded $\mathrm{H}$ to the mineral surface (Biró et al., 2016; Stalder, 2021), or it can be assigned to $\mathrm{Si}-\mathrm{O}$ bonds (Kats,
1962). Nevertheless, assignation of this peak remained controversial (Stalder, 2021). The estimation of original magmatic water content using quartz as a NAM and its melt inclusions can be challenging due to syn- and post-eruptive processes, which can modify (reduce in most cases) the structural hydroxyl content of the NAM (Biró et al., 2017). H diffusion in natural quartz is isotropic and relatively fast at volcanic temperatures $\left(700-800^{\circ} \mathrm{C}\right)$ on the order of $10^{-10}$ to $10^{-14} \mathrm{~m}^{2} \mathrm{~s}^{-1}$ (Kats 1962; Kronenberg et al., 1986; Jollands et al., 2020b). This diffusivity is fast enough to produce diffusion profiles, which are applicable for the determination of timescales of magma ascent rates and eruption history (Myers et al., 2018, 2019; Tollan et al., 2019; Jollands et al., 2020b). However, this rapid diffusion is also sufficient to lose a significant portion of the original $\mathrm{H}$ content of the quartz phenocrysts exposed to high temperatures $\left(300-700^{\circ} \mathrm{C}\right)$ for time intervals ranging from days to months under decreasing water activity (e.g., degassing, slow cooling at the surface; Biró et al., 2017; Stalder et al., 2017). Another problem is the $\mathrm{Li}$ vs. $\mathrm{H}$ competition for the charge-balancing position connected to $\mathrm{Al}$, because $\mathrm{Li}$ is also highly mobile and can be characterized with fast diffusion (Tollan et al., 2019). However, recent studies imply that $\mathrm{Li}$ compensates for the $\mathrm{Al}$ caveats to the detriment of $\mathrm{H}$, when the water activity in melt drops significantly, but Li activity remains the same (Tollan et al., 2019; Jollands et al., 2020b). This means that during ascension of the magma, a little amount of $\mathrm{H}$ diffuses out from the rims of quartz crystal, and $\mathrm{Li}$ enters into the structure to compensate for the charge balance which was broken by the dehydration (Tollan et al., 2019). Other elements (e.g., major elements, like Na) possibly do not play a significant role in charge balancing of $\mathrm{Al}$ in competition with $\mathrm{H}$ because they diffuse much more slowly (Cherniak and Dimanov, 2010; Zhang et al., 2010).

In volcanic systems, for example, in the case of thick, pumice-bearing pyroclastic density current (PDC) deposits, such as ignimbrites, the long-lasting (days to months) hightemperature conditions $\left(300-700^{\circ} \mathrm{C}\right.$, Gleadow et al., 2015; Pensa et al., 2015; Biró et al., 2017; Madden-Nadeau and Genge, 2019) after deposition can cause significant (or even complete) water loss from the quartz phenocrysts (Biró et al., 2017). In contrast, quartz phenocrysts of pyroclastic fallout deposits can keep the original structural hydroxyl content due to the relatively rapid cooling of the pyroclasts ( 1 to $10^{\circ} \mathrm{C} \mathrm{s}^{-1}$; according to Wallace et al., 2003) in comparison with the PDCs (Wallace et al., 2003; Lloyd et al., 2013; Potrafke et al., 2019; Jollands et al., 2020b).

In this study, we report $\mathrm{AlOH}$ structural hydroxyl concentrations of quartz phenocrysts from five Miocene pyroclastic fallout deposits of the Bükk Foreland Volcanic Area (BFVA hereafter), northern Hungary, Carpathian-Pannonian region (Fig. 1), and two pyroclastic fallout deposits of the AD 1314 Kaharoa eruption, Tarawera, New Zealand (KH eruption hereafter). The studied pyroclastic fallout deposits were selected in order to minimize the effect of post- and 


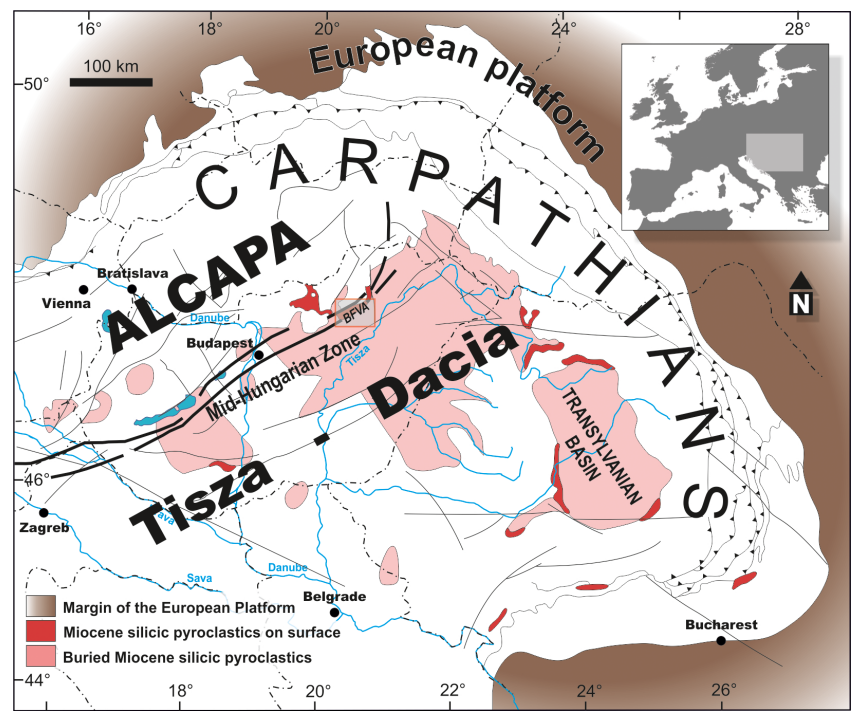

Figure 1. Distribution of Miocene felsic pyroclastics within the Pannonian Basin (Central Europe). BFVA - Bükk Foreland Volcanic Area. The map was modified after Pécskay et al. (2006). The occurrence of buried pyroclastics is based on drillings. The main structural lines (solid line) and the main faults (black triangles) are indicated.

syn-eruptive hydrogen loss (Wallace et al., 2003; Jollands et al., 2020b); thus presumably their AlOH structural hydroxyl content can be used to infer the original water content of the host magma. Furthermore, in this way, we investigate whether the structural hydroxyl content of quartz phenocrysts depends on any volcanological conditions (such as lateral distance from the vent, stratigraphic position, welding of the covering deposit, etc.). The most important factors controlling the structural hydroxyl content of quartz in felsic volcanic systems producing explosive eruptions are discussed.

\section{Geodynamic setting and volcanism}

\subsection{Silicic magmatic systems - BFVA eruptions and KH eruption}

In silicic systems the uppermost level of the magmatic plumbing system is characterized by distinct magma batches containing crystal mush and melt lenses (Gualda et al., 2018). The eruptible magma could be stored at around 1.5 to $2 \mathrm{kbar}$ pressure (i.e., $6-7 \mathrm{~km}$ below the surface), characterized by a bunch of sill- and dyke-shaped bodies and other small, long-lived magma pockets (Matthews et al., 2012; Kennedy et al., 2018; Gualda et al., 2019; Huber et al., 2019). However, recent studies suggest a shallower $(0.5-1.5 \mathrm{kbar}$ pressure zone) emplacement of magma bodies, where the last step of the crystallization and segregation of the eruptible melt occur just before eruption (Graeter et al., 2015; Tol- lan et al., 2019). The root of the magmatic plumbing system may go down as far as the mantle-crust boundary, which is the so-called MASH zone (melting, assimilation, storage and homogenization; Hildreth and Moorbath, 1988).

Magmatic storage system of the BFVA was presumably initiated in the Early Miocene with long-lasting (starting from ca. 18.5 Ma according to Lukács et al., 2018) subvolcanic activity, which created a complex, multi-level magmatic reservoir in the upper crust (for hundreds of kiloyears) with several shallow silicic melt pockets, which fed the eruptions via magma mingling (Harangi et al., 2005; Lukács et al., 2005, 2015, 2018). The bimodality of the chemical composition of some units (andesitic and rhyolitic; Póka et al., 1998) suggests that the partial melting of the asthenosphere and lithospheric mantle produced mafic melts, which were stalled in the vicinity of the mantle-crust boundary (Lukács et al., 2005, 2018) and evolved at mid-crustal levels (Póka et al., 1998; Cooper et al., 2016; Kósik et al., 2019, 2020). The extensional thinning of the lithosphere had already taken place by the Late Miocene, which favored the ascent of mafic magmas from lower crustal reservoirs into the upper crust (Csontos et al., 1992; Lukács et al., 2018; Petrik et al., 2019). The best analogue for the magmatic system and for the volcanism of the BFVA could be the Taupo Volcanic Zone in terms of volcanic morphology (nested calderas; Wilson, 1993, 2001), topography (lowland setting, possible influence of sea or lake water; Wilson, 2001; Biró et al., 2020), geodynamic setting (extensional back-arc, normal fault systems), existence of rift zones (Wilson and Walker, 1985, 1993, 2001; Graham et al., 1995; Szakács et al., 1998; Nairn et al., 2004; Wilson and Rowland, 2016; Stagpoole et al., 2020), and volcanic eruption styles (silicic Plinian ignimbrite-forming eruptions, phreatoplinian eruptions, small-scale silicic monogenetic eruptions; Szakács et al., 1998; Lukács et al., 2005, 2018; Barker et al., 2020; Biró et al., 2020; Kósik et al., 2020; Hencz et al., 2021a; b).

In recent models of the magmatic system of the $\mathrm{KH}$ eruption, a single, stratified magma chamber was suggested based on geochemical features of different magmatic products (Nairn et al., 2004). Mafic magma recharge was obvious throughout the lifetime of the magmatic system, which may have triggered the eruptions but could not destroy the layered (in terms of silica content) magma chamber (Leonard et al., 2002; Nairn et al., 2004, 2005). The depth of the uppermost level of the Taupo Volcanic Zone (TVZ) system (where the KH magma originated from) was calculated to be between 6 and $7 \mathrm{~km}$ (1.6-2 kbar pressure) based on mineral thermobarometry and glass composition (Ewart et al., 1975; Nicholls et al., 1992; Blundy and Cashman, 2001).

\subsection{Tectonic setting of the BFVA}

During the Early to Mid-Miocene large-scale silicic volcanism was taking place in the Carpathian-Pannonian region (Schréter, 1939; Szakács et al., 1998; Lukács et al., 2018). 
This felsic calc-alkaline magmatism was preceded by various subduction stages, which re-fertilized the lithospheric mantle and asthenosphere, allowing partial melting via volatile fluxing (Szabó et al., 1992; Kovács and Szabó, 2008). During the eastward movement and rotation of the ALCAPA (Alpine-Carpathian-Pannonian) microplate (Fig. 1), lithospheric thinning was taking place in the inner part of the ALCAPA microplate of which the exact driving mechanism is still debated (Csontos et al., 1992; Horváth, 1993; Márton and Márton, 1996; Márton et al., 2007; Kovács et al., 2012; Horváth et al., 2015; Balázs et al., 2016). During the rotation normal faults were formed in the crustal part of ALCAPA (Csontos et al., 1992). Due to the re-fertilization of the mantle (i), crustal thinning in the ALCAPA block (ii), and normal fault propagation in the crust (iii), silica-rich melts formed via fractional crystallization and crustal assimilation, erupting through large-scale ignimbrite-forming explosive volcanic activity on the eastern part of ALCAPA between ca. 18 and 14 Ma based on zircon U-Pb ages (Lukács et al., 2015, 2018). The deposits generated by the prevailingly explosive volcanism (pyroclastic fallout deposits, PDC deposits, reworked tephras) are now buried under Late Miocene-Quaternary sediments and crop out continuously in coherent condition in a narrow $(40 \times 10 \mathrm{~km})$ belt between the Mesozoic sedimentary block of the Bükk Mountains and the Great Hungarian Plain (Fig. 1). The most voluminous deposits are ignimbrites showing different facies (welded, nonwelded, distal, etc.), but pyroclastic fallout horizons occasionally also occur (Capaccioni et al., 1995; Szakács et al., 1998; Biró et al., 2020; Hencz et al., 2021a, b).

For the present study, we sampled pyroclastic fallout layers from two different parts of the stratigraphic column (Table 1 and Fig. 2), which represents different episodes (i.e., age intervals) of the volcanism: from the middle part of the Lower Pyroclastic Complex (LPC, base of the Mangó ignimbrite unit of Lukács et al., 2018) and from the lowest part of the Upper Pyroclastic Complex (UPC, right above the Jató member distinguished by Biró et al., 2020).

\subsection{The AD 1314 Kaharoa eruption, New Zealand (KH eruption)}

The KH eruption occurred at AD $1314( \pm 12)$ in the North Island of New Zealand (Lowe et al., 1998; Newnham et al., 1998; Hogg et al., 2003; Klemetti and Cooper, 2007; Robertson, 2007) in an extensional geotectonic setting inside a continental plate (Graham et al., 1995). The main rhyolitic volcanic zone in New Zealand is situated in the Taupo Volcanic Zone (TVZ hereafter), where the volcanic activity began around $2 \mathrm{Ma}$ with andesitic activity, which marks the transition of the volcanic activity from the older Coromandel Volcanic Zone (CVZ) to the TVZ (Wilson et al., 1995; Gravley et al., 2016) (Fig. 3). The volcanism of the TVZ can be divided into two large time periods: 20.7 Ma, when andesite-dominated volcanism occurred, and

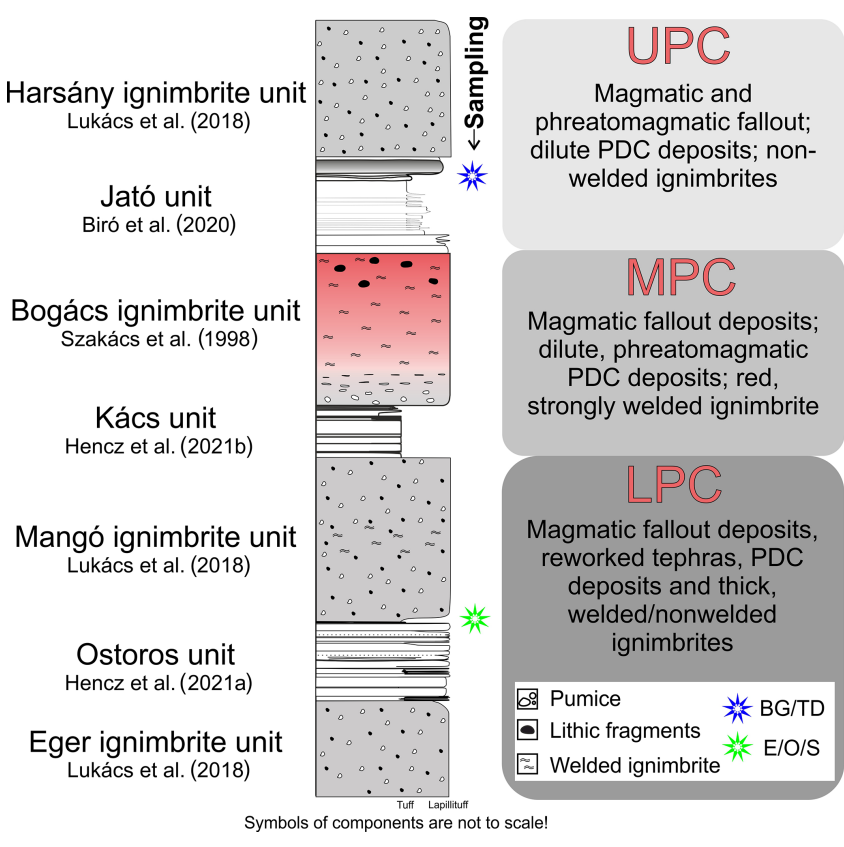

Figure 2. Simplified stratigraphical column of the BFVA and the three main pyroclastic complexes with their basic volcanological description based on former studies (LPC: Lower Pyroclastic Complex, MPC: Middle Pyroclastic Complex, UPC: Upper Pyroclastic Complex; Szakács et al., 1998; Márton and Pécskay, 1998; Márton et al., 2007). The sampling points are indicated with stars.

0.7-present, which is dominated by rhyolitic volcanism in the form of large-scale ignimbrite-forming explosive volcanism and caldera-forming eruptions (Deering et al., 2011). The ascendent transport of the melts was facilitated by fault zones (Wright, 1992; Graham et al., 1995). In recent times, several calderas occupied the central TVZ (e.g., Whakamaru, Mangakino, Kapenga; Wilson et al., 1995), and the eruption center of the KH eruption occurred at the Tarawera volcano intra-caldera rhyolite-dome complex within the Haroharo caldera of the Okataina Volcanic Centre, located at the northern-central part of the TVZ (Graham et al., 1995; Lowe et al., 1998; Nairn et al., 2001, 2004; Sahetapy-Engel et al., 2014) (Fig. 3). Explosive volcanic activity occurred from seven vents spread along an $8 \mathrm{~km}$ long lineament (Graham et al., 1995; Nairn et al., 2001). The eruptions were fed by three (and one mixed) rhyolite magma batches with slightly varying geochemistry (Nairn et al., 2004). Largescale pyroclastic fallout activity dominated the volcanism, producing well-identifiable fallout horizons across the region (Sahetapy-Engel et al., 2014).

For this study, two pyroclastic fallout horizons of the KH eruption were sampled representing the early, high-silica content rhyolitic phase of the volcanism, originating from well-known outcrops (Table 1). 
Table 1. Location of the sampled pyroclastic fallout deposits and their relative regional stratigraphic positions with basic volcanological descriptions (based on recent works).

\begin{tabular}{|c|c|c|c|c|c|}
\hline $\begin{array}{l}\text { Name of sites } \\
\text { (abbreviation) }\end{array}$ & $\begin{array}{l}\text { Sampling } \\
\text { location }\end{array}$ & $\begin{array}{l}\text { Relative stratigraphic } \\
\text { position }\end{array}$ & Physical volcanological features & $\begin{array}{l}\text { Main features of quartz } \\
\text { phenocrysts }\end{array}$ & Reference \\
\hline $\begin{array}{l}\text { BFVA } \\
\text { Bogács wine } \\
\text { cellars (BG) } \\
\text { Tibolddaróc wine } \\
\text { cellars (TD) - } \\
\text { both Unit III/A/2 of } \\
\text { Biró et al. (2020) }\end{array}$ & $\begin{array}{l}\text { BG } \\
47.8964^{\circ} \mathrm{N}, \\
20.5276^{\circ} \mathrm{E} \\
\mathrm{TD} \\
47.9256^{\circ} \mathrm{N} \\
20.6317^{\circ} \mathrm{E}\end{array}$ & $\begin{array}{l}\text { Bottom of the Upper } \\
\text { Pyroclastic Complex. } \\
\text { Upper Middle Tuff } \\
\text { Complex of Szakács et } \\
\text { al. (1998), } \\
\text { Right above Jató } \\
\text { member of Biró et } \\
\text { al. (2020) }\end{array}$ & $\begin{array}{l}\text { This sequence (Unit III/subunit A in Biró et } \\
\text { al., 2020) built up by } 3-20 \mathrm{~cm} \text { thick coarse, } \\
\text { well-sorted tuff layers containing pumice } \\
\text { clasts, lithic clasts, and millimeter-sized } \\
\text { quartz, feldspar, and biotite phenocrysts. } \\
\text { These layers were interpreted as pyroclas- } \\
\text { tic fallout horizons. }\end{array}$ & $\begin{array}{l}\text { The separated quartz } \\
\text { phenocrysts are up to } \\
1 \mathrm{~mm} \text { in diameter and } \\
\text { are euhedral, bipyrami- } \\
\text { dal crystals. }\end{array}$ & $\begin{array}{l}\text { Szakács et al. (1998) } \\
\text { Lukács et al. (2015) } \\
\text { Biró et al. (2020) }\end{array}$ \\
\hline $\begin{array}{l}\text { BFVA } \\
\text { Eger - } \\
\text { Tufakőbánya (E) } \\
\text { Ostoros - Arany } \\
\text { János street (O) } \\
\text { Sály - Latorvár (S) }\end{array}$ & $\begin{array}{l}\mathrm{E} \\
47.885658^{\circ} \mathrm{N}, \\
20.404073^{\circ} \mathrm{E} \\
\mathrm{O} \\
47.859809^{\circ} \mathrm{N}, \\
20.439418^{\circ} \mathrm{E} \\
\mathrm{S} \\
47.978067^{\circ} \mathrm{N}, \\
20.641505^{\circ} \mathrm{E}\end{array}$ & $\begin{array}{l}\text { Lower Pyroclastic } \\
\text { Complex. } \\
\text { Base of the Mangó ig- } \\
\text { nimbrite unit of Lukács } \\
\text { et al. (2018), } \\
\text { Upper Lower Tuff } \\
\text { Complex of Szakács et } \\
\text { al. (1998) }\end{array}$ & $\begin{array}{l}\text { A pyroclastic fallout horizon was sam- } \\
\text { pled at the base of the Mangó ignimbrite } \\
\text { unit (following the nomenclature of Lukács } \\
\text { et al., 2018). This layer was sampled in } \\
\text { three different geographical sites (E, O, S). } \\
\text { This is a well-sorted, topography-mantling } \\
\text { layer and contains pumice fragments, lithic } \\
\text { clasts, ash matrix in lower volume, and } \\
\text { phenocrysts, such as quartz, biotite, and } \\
\text { feldspar. The deposit is the thickest in the } \\
\text { eastern BFVA at Sály (Latorvár, in the } \\
\text { southern slope of the hill; S), where it is } \\
\sim 70 \mathrm{~cm} \text {, and it is the thinnest in a mine near } \\
\text { the town of Eger, where it is only } 20 \mathrm{~cm} \\
\text { thick. Underneath there is a brown paleosol, } \\
\text { and over the fallout horizon there is de- } \\
\text { posit from dilute PDC showing faint cross- } \\
\text { bedding ( } 20 \mathrm{~cm} \text { in thickness) and topped } \\
\text { with a min. } 30 \mathrm{~m} \text { thick non-welded ign- } \\
\text { imbrite in Eger and Ostoros and with a } \\
\text { welded ignimbrite in Sály. The pyroclas- } \\
\text { tic fallout material was deposited in an } \\
\text { early phase of the eruption which created } \\
\text { the overlying thick Mangó ignimbrite. The } \\
\text { eruption center could have been in the larger } \\
\text { vicinity of Sály. }\end{array}$ & $\begin{array}{l}\text { The separated quartz } \\
\text { phenocrysts are rela- } \\
\text { tively large, over } 1 \mathrm{~mm} \\
\text { in diameter, euhedral, } \\
\text { and bipyramidal. Melt } \\
\text { inclusions are common. }\end{array}$ & $\begin{array}{l}\text { Capaccioni et } \\
\text { al. (1995) } \\
\text { Szakács et al. (1998) } \\
\text { Biró et al. (2017) } \\
\text { Lukács et al. (2018) } \\
\text { Hencz et al. (2021a) }\end{array}$ \\
\hline $\begin{array}{l}\text { New Zealand } \\
\text { Kaharoa eruption } 1 \\
\text { (KH1) } \\
\text { Kaharoa eruption } 2 \\
(\mathrm{KH} 2)\end{array}$ & $\begin{array}{l}\mathrm{KH} 1 \\
38.309475^{\circ} \mathrm{S}, \\
176.530969^{\circ} \mathrm{E} \\
\mathrm{KH} 2 \\
38.286728^{\circ} \mathrm{S}, \\
176.516217^{\circ} \mathrm{E}\end{array}$ & $\begin{array}{l}\text { KH1 sample originates } \\
\text { from the lowermost bed } \\
\text { of the Kaharoa } \\
\text { eruption, correlatable } \\
\text { with the A bed of } \\
\text { Sahetapy-Engel et } \\
\text { al. (2014). KH } 2 \text { origi- } \\
\text { nated from the middle } \\
\text { part of the fallout layer } \\
\text { over explosion breccia } \\
\text { of Sahetapy-Engel et } \\
\text { al. (2014) }\end{array}$ & $\begin{array}{l}\text { KH1 sampling site is near K } 48 \text { of Sahetapy- } \\
\text { Engel et al. (2014). } \\
\text { KH2 sampling site is equivalent of the } \\
\text { K270 location of Sahetapy-Engel et } \\
\text { al. (2014). } \\
\text { The sampled layer is the same in both } \\
\text { cases: layer A of Sahetapy-Engel et } \\
\text { al. (2014), which consists of fallout-lapilli } \\
\text { with the capping ash. The dispersal was } \\
\text { mainly towards the southeast. This is the } \\
\text { first lapilli-ashfall of the KH eruption } \\
\text { with regional dispersal. Below this bed, an } \\
\text { explosion breccia crops out, very visible } \\
\text { in the case of site KH2. The capping } \\
\text { pyroclastic sediment is a lapilli fall deposit } \\
\text { (layer B in Sahetapy-Engel et al., 2014) }\end{array}$ & $\begin{array}{l}\text { The separated quartz } \\
\text { phenocrysts are small, } \\
\text { about } 500 \mu \mathrm{m} \text { in di- } \\
\text { ameter, euhedral, and } \\
\text { bipyramidal. Melt } \\
\text { inclusions are very } \\
\text { common and some- } \\
\text { times contain bubbles. }\end{array}$ & $\begin{array}{l}\text { Sahetapy-Engel et } \\
\text { al. (2014) } \\
\text { Nairn et al. (2001, } \\
2004)\end{array}$ \\
\hline
\end{tabular}

\section{Methods and sampling}

\subsection{Sampling and sample preparation}

The middle part of individual pyroclastic fallout layers was sampled. When the rock was slightly cemented, the sampling was made by using a hammer. Then, the sample was crushed by hand and washed. After drying (at $60^{\circ} \mathrm{C}$ for $180 \mathrm{~min}$ ) the crushed bulk sample was sieved to separate the $0.5-2 \mathrm{~mm}$ fraction. About 30 quartz phenocrysts were separated from each layer in the mentioned grain-size fraction under a binocular microscope. Euhedral and subhedral bipyramidal quartz phenocrysts were preferred for selection.

The phenocrysts were polished on two sides following the protocol described in Biró et al. (2016). The phenocrysts were then placed on a glass plate and were embedded into gel glue (Loctite ${ }^{\circledR}$ Super Bond Power Flex Gel glue) in an unoriented manner. The mounts were ground using $\mathrm{Al}_{2} \mathrm{O}_{3}$ powder until all the separated phenocrysts became uniformly exposed ( $\sim 600-700 \mu \mathrm{m}$ in thickness), and then they were 


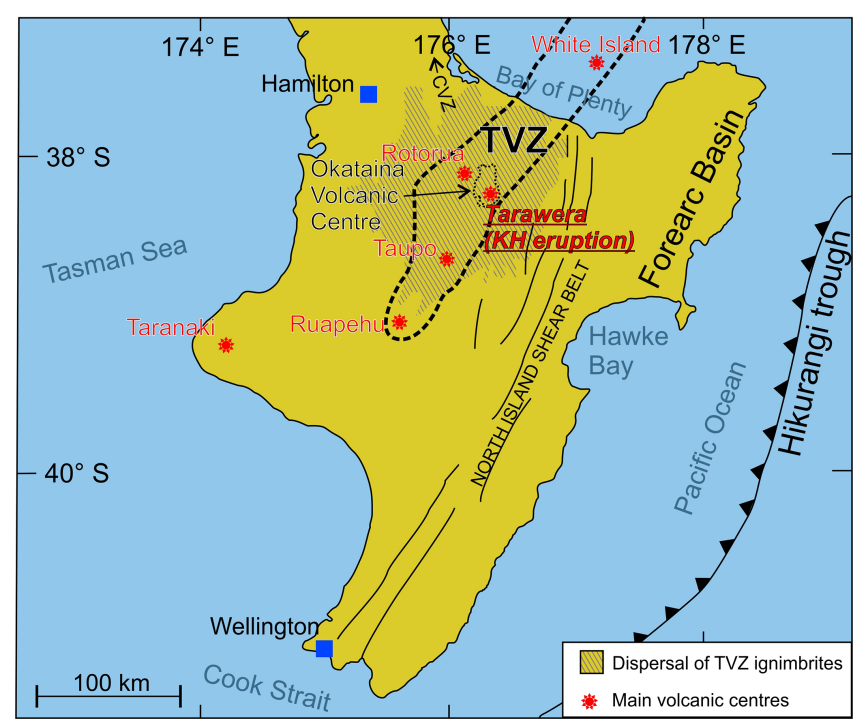

Figure 3. Tectonic environment of the TVZ (Taupo Volcanic Zone) and the main volcanic centers, including the Tarawera silicic dome complex, where the AD 1314 Kaharoa eruption occurred. The main structural lines (solid line) are indicated. CVZ: Coromandel Volcanic Zone. Modified after Graham et al. (1995), Briggs et al. (2005), and Kósik (2018).

polished with $\mathrm{Al}_{2} \mathrm{O}_{3}$ suspension. The mounts were dissolved with acetone from the supporting glass slide and then the phenocrysts were turned to their other side and were again attached to the glass slide with liquid adhesive (Loctite ${ }^{\circledR} \mathrm{Su}$ per Bond Universal liquid glue). The mounts were ground to $\sim 250 \mu \mathrm{m}$ thickness to be suitable for micro-FTIR measurements (Biró et al., 2016), then they were polished again with $\mathrm{Al}_{2} \mathrm{O}_{3}$. They were separated from the glass plate, washed in running water, and dried out at $90^{\circ} \mathrm{C}$ for $2 \mathrm{~h}$.

\subsection{Peculiarities of the sample preparation}

In the case of quartz phenocrysts with homogenous water content (when melt inclusions are relatively rare in the crystal), unpolarized absorbances of hydroxyl-related bands should ideally vary between predicted minimum and maximum values as follows from the unpolarized absorbance indicatrix of quartz (Kovács et al., 2008; Sambridge et al., 2008; Stalder and Konzett, 2012; Biró et al., 2017). A theoretical consideration for unpolarized measurements was given earlier (Kovács et al., 2008; Sambridge et al., 2008), a recent work also referred to the strategy of polarized measurements on oriented grains (Stalder and Konzett, 2012), while the connection was given between the polarized and unpolarized absorbance indicatrix of Al-related hydroxyl defects in quartz (Biró et al., 2016). Applying unpolarized IR radiation for the measurements, we get the maximum absorbance when the incident infrared radiation travels parallel to the crystallographic $c$ axis. In contrast, unpolarized absorbance is minimal when the incoming light travels per-

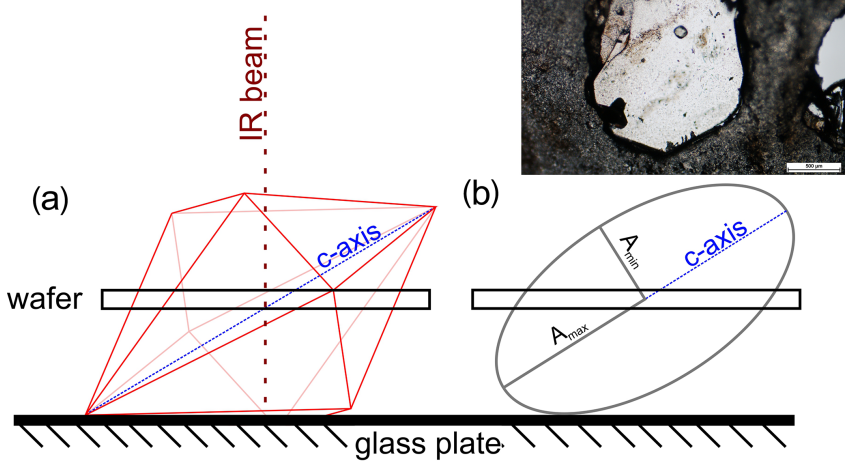

Figure 4. The theoretical relation between unpolarized absorbance of quartz and crystal orientation. (a) A hypothetic euhedral quartz phenocryst (similar to those prepared) as laid on the glass plate onto its pyramidal facet. "Wafer" refers to the section resulting after sample preparation (doubly polished thick section). (b) The unpolarized absorbance indicatrix of a quartz crystal with identical orientation as in (a) (Biró et al. 2017) (c) quartz wafer in epoxy resin after sample preparation.

pendicular to the $c$ axis; in this case the absorbance should be ideally half of what is measured in the former case, because of the orientation of the hydroxyl dipole perpendicular to the $c$ axis (as summarized by Biró et al., 2017). Our first round of measurements implied that the applied sample preparation will result in an overrepresentation of lower absorbances (i.e., the incident light is most often almost perpendicular to the $c$ axis). This is due to the fact that the euhedralsubhedral bipyramidal crystals were laid on the glass plate on their pyramidal facets or prism surfaces (Fig. 4). Thus, the measured absorbances may be slightly lower than if the grains were perfectly unoriented. Perfectly unoriented grains mean that the direction of the incident light is equally distributed over a sphere with respect to the absorbance indicatrix (see Kovács et al., 2008; Biró et al., 2017, for more discussion). Since the preparation of the samples was consistent and similar in each case, the results are comparable to each other, and the real concentrations are expected to be underestimated by the same extent. To follow up this "unperfect unorientation" issue, manually crushed crystals were prepared (see Appendix A). The results assured us that (1) the crushed crystals can retrieve accurate absolute concentrations. (2) Thus we could quantitatively constrain the degree of underestimation with the currently applied methodology (in contrast with the one applied in Biró et al., 2017). (3) The determined concentrations with the applied methodology are robust for exploring relative variations quantitatively. 


\subsection{FTIR methodology}

The IR spectra of the quartz wafers were recorded in a temperature-controlled laboratory at the HAS RCAES with a Bruker ${ }^{\circledR}$ Hyperion 2000 IR microscope attached to a Bruker $^{\circledR}$ Vertex 70 spectrometer. We used unpolarized FTIR methodology in light of indicatrix theory for unpolarized light (Kovács et al., 2008; Sambridge et al., 2008). This makes it possible to determine the structural hydroxyl content of anisotropic crystals when the following conditions are met: (1) at least a few crystals are measured from the same population $(>5),(2)$ the crystals are unoriented with respect to the incident IR light, (3) structural hydroxyl content is homogenous within and among crystals, and (4) maximum linear absorbance of the spectra in the hydroxyl region (roughly between 3000 and $3500 \mathrm{~cm}^{-1}$ ) does not exceed 0.15 (Kovács et al., 2008; Sambridge et al., 2008).

During the FTIR measurements the aperture was $50 \times$ $50 \mu \mathrm{m}$. The spectra were recorded with 128 scans, with $4 \mathrm{~cm}^{-1}$ spectral resolution between $400-4000 \mathrm{~cm}^{-1}$. During the measurements, atmospheric compensation of the OPUS ${ }^{\circledR}$ software was used to eliminate the contribution of water vapor and $\mathrm{CO}_{2}$ from the atmosphere. The spectra were obtained carefully from parts of the crystal wafers where melt or fluid inclusions were not visible. Measurements along transects and in crystal cores and rims were also acquired in order to investigate the intra-crystal variations in the structural hydroxyl content.

The obtained spectra then were processed using the OPUS $^{\circledR}$ software. The integration was calculated using the "B-type" integration method of the OPUS ${ }^{\circledR}$ software (Fig. 5; see Fig. 2 of Biró et al., 2016, and Fig. S3 of Reynes et al., 2018). The B-type integration includes the area above a line connecting the intersections of the lower and upper limits of integration (Fig. 5). Thus, baseline correction was not necessary, because it could cause a significant underestimation of the real structural hydroxyl content. Moreover, using the Btype integration, the possible contribution of molecular water can be minimalized, because it takes into account only the bands that correspond to the structural hydroxyl signal and not the abovementioned wide and flat band of molecular $\mathrm{H}_{2} \mathrm{O}$. Structural hydroxyl is more stable and better preserved in the phenocryst than the molecular $\mathrm{H}_{2} \mathrm{O}$, which is more sensitive to external influences (heat, pressure, chemical activity, etc.). The integration boundaries are given in Table 2. The structural hydroxyl content of the quartz phenocrysts was calculated using the modified Beer-Lambert law (Eq. 1):

$c=\frac{A_{\mathrm{tot}} \cdot M_{i}}{\varepsilon_{i} \cdot \rho \cdot t}$,

where $c$ is the calculated water concentration (in $\mathrm{H}_{2} \mathrm{O}$ wt ppm); $A_{\text {tot }}$ is the total polarized absorbance; $M_{i}$ is the molar weight of the water (in $\mathrm{g} / \mathrm{mol}$ ); $\varepsilon_{i}$ is the integrated absorption coefficient (where $94000 \pm 20000 \mathrm{~L} / \mathrm{mol} \mathrm{cm}^{-2}$ was used according to Thomas et al. (2009), because this number had been established from measurements from natural quartz phenocrysts, of which the spectrum was identical to the spectra in the case of volcanic quartz phenocrysts); $\rho$ is the density of the phenocryst $(2650 \mathrm{~g} / \mathrm{L})$; and $t$ is the thickness of the sample. The total polarized absorbance was calculated as 3 times the (average) integrated unpolarized absorbance of bands caused by $\mathrm{AlOH}$ structural hydroxyl substitution (centered at 3430,3378 , and $3315 \mathrm{~cm}^{-1}$ ), which are dominant in the hydroxyl region of the IR spectra. The minor bands (such as at 3483 or at $3200 \mathrm{~cm}^{-1}$ ) are negligible and were not included into the total structural hydroxyl content. The thickness was calculated using the method described by Biró et al. (2016) according to Eq. (2):

$y=3.3089 x \pm 15 \%$,

where $x$ is the sample thickness in micrometers and $y$ is the integrated area of Si-O bands between $2110-1440 \mathrm{~cm}^{-1}$. The structural hydroxyl contents are expressed in molecular water equivalent and are related to the $\mathrm{AlOH}$ structural hydroxyl content (Table 2) and characterized by typically $\pm 15 \%$ cumulative uncertainty. The unit we used ("wt ppm") means wt ppm $\mathrm{H}_{2} \mathrm{O}$. Note that we also calculated "indicative" water concentrations for individual measurements from a given sample population, which, in the ideal case, varies only due to the variation in the direction of the incident light with respect to the absorbance indicatrix. Also note that the average of these measurements from a population of unoriented crystals can be used to estimate the true absolute structural hydroxyl content.

\section{FTIR spectra and structural hydroxyl content of the quartz phenocrysts}

Total evaluation, including the exact calculations, can be found in Supplement files S1 and S2. The summarized analytical results can be found in Table 3. The average unpolarized spectra for each layer are shown in Fig. 5, including the calculated structural hydroxyl contents and the cumulative uncertainty in brackets. The results depicted in the box-andwhisker plot are displayed in Fig. 6.

\subsection{Eger (E), Ostoros (O), and Sály (S) sites (all samples from the same fallout horizon of the LPC)}

The hydroxyl region of the spectra is dominated by three sharp bands, the largest of which is centered at $3379 \mathrm{~cm}^{-1}$, and the two smaller ones are centered at 3314 and $3430 \mathrm{~cm}^{-1}$. A minor weak band is present at $3478 \mathrm{~cm}^{-1}$, but in some wafers it is absent. Another minor band can also be observed at $3197 \mathrm{~cm}^{-1}$ in the case of all samples. The broad band centered at $\sim 3400 \mathrm{~cm}^{-1}$ associated with molecular water was not registered.

The indicative structural hydroxyl content of the phenocrysts is in the range of $6.8-15.1,7.0-14.1$, and 6.4 $12.8 \mathrm{wt} \mathrm{ppm}$ in the case of $\mathrm{E}, \mathrm{O}$, and $\mathrm{S}$ samples, respectively. 


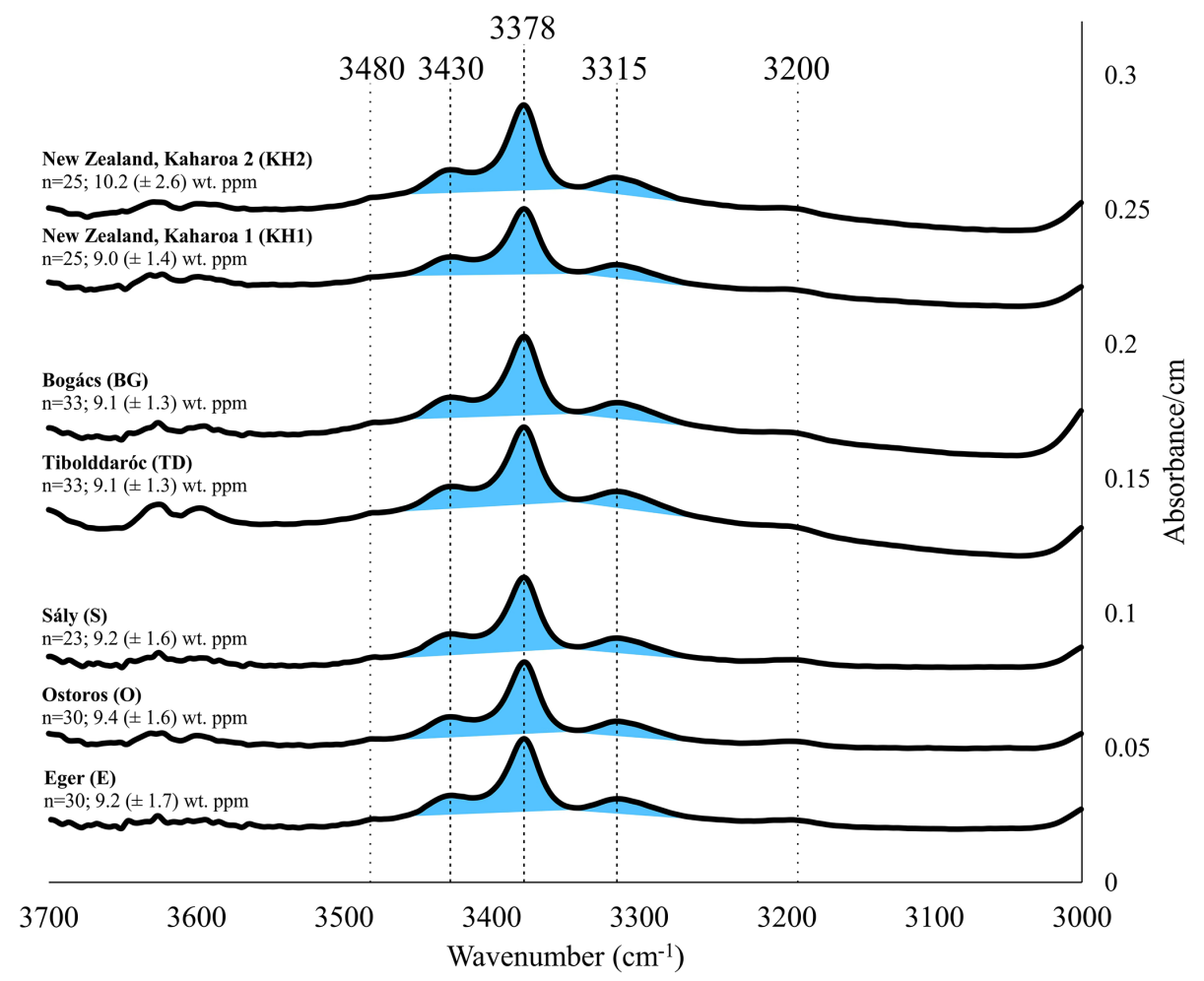

Figure 5. Hydroxyl region of average spectra. The calculated structural hydroxyl content of each sample is indicated with $\pm 15 \%$ analytical uncertainty. $n$ : number of the measured phenocrysts. Blue areas represent the integrated area using OPUS ${ }^{\circledR}$ B-type integration, on the basis of which the structural $\mathrm{OH}$ contents were calculated.

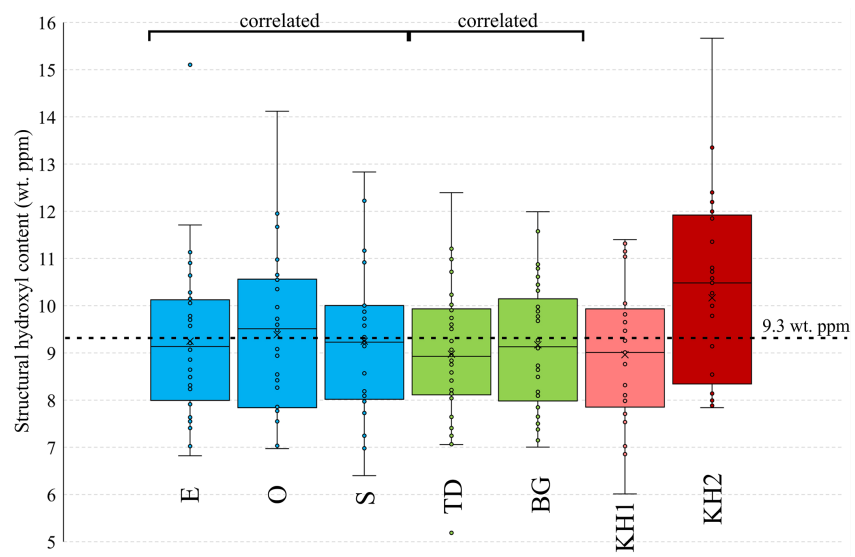

Figure 6. Box-and-whisker plot of the measured structural hydroxyl contents. The sampling sites of the same layer are marked as "correlated". The dashed black line shows the average of the whole dataset (9.3 wt ppm).

The calculated structural hydroxyl contents are $9.2( \pm 1.7)$, 9.4 ( \pm 1.6$)$, and $9.2( \pm 1.6) \mathrm{wt}$ ppm (standard deviations in brackets).

\subsection{Tibolddaróc (TD) and Bogács (BG) sites (all samples from the same fallout horizon of the UPC)}

The triplet with a main band at $3379 \mathrm{~cm}^{-1}$ and minor bands at 3314 and $3430 \mathrm{~cm}^{-1}$ is clearly visible and dominates the hydroxyl region of the spectra. The $\mathrm{LiOH}$ band $\left(3478 \mathrm{~cm}^{-1}\right)$ is not visible (or very minor) in both the TD and BG samples. However, a sharper but minor band can be clearly seen at $3197 \mathrm{~cm}^{-1}$.

The calculated structural hydroxyl content in TD is 9.1 $( \pm 1.3) \mathrm{wt} \mathrm{ppm}$, and the indicative concentrations are in the range of 7.1 to $12.4 \mathrm{wt} \mathrm{ppm}$. In the case of BG, the calculated value is $9.1( \pm 1.3) \mathrm{wt}$ ppm, and the measured values are in the 7.1-12.0 wt ppm range.

\subsection{KH eruption sites}

The hydroxyl region is dominated by the $\mathrm{AlOH}$ triplet centered at 3314,3379 , and $3430 \mathrm{~cm}^{-1}$, similar to the BFVA samples. The LiOH band $\left(3478 \mathrm{~cm}^{-1}\right)$ is visible with low intensity. A very minor band can be seen at $3197 \mathrm{~cm}^{-1}$.

The calculated structural hydroxyl content of the KH1 sample is $9.0( \pm 1.4) \mathrm{wt} p \mathrm{pm}$. The indicative structural hydroxyl contents are in the range of 6.0 to $11.4 \mathrm{wt} \mathrm{ppm}$. In the case of the KH2 sample, the structural hydroxyl content is slightly higher, $10.2( \pm 2.6) \mathrm{wt}$ ppm. The range of the struc- 
Table 2. Integration boundaries and their interpretation. Bands in bold are used for the calculation of structural hydroxyl content of quartz phenocrysts in this work.

\begin{tabular}{|c|c|c|c|c|c|}
\hline Name & $\begin{array}{l}\text { Upper limit } \\
\left(\mathrm{cm}^{-1}\right)\end{array}$ & $\begin{array}{l}\text { Lower limit } \\
\qquad\left(\mathrm{cm}^{-1}\right)\end{array}$ & $\begin{array}{l}\text { Type of integration } \\
\text { (OPUS }{ }^{\circledR} \text { software) }\end{array}$ & Interpretation & References \\
\hline 3480 & 3502 & 3469 & B & LiOH defects & $\begin{array}{l}\text { Stalder and Konzett (2012) } \\
\text { Frigo et al. (2016) } \\
\text { Potrafke et al. (2020) }\end{array}$ \\
\hline 3430 & 3467 & 3413 & B & $\begin{array}{l}\text { AlOH structural hydroxyl de- } \\
\text { fects }\end{array}$ & $\begin{array}{l}\text { Kats (1962) } \\
\text { Stalder and Konzett (2012) }\end{array}$ \\
\hline 3378 & 3400 & 3351 & B & $\begin{array}{l}\text { AlOH structural hydroxyl de- } \\
\text { fects }\end{array}$ & $\begin{array}{l}\text { Kats (1962) } \\
\text { Stalder and Konzett (2012) }\end{array}$ \\
\hline $3430+3378$ & 3467 & 3351 & B & $\begin{array}{l}\text { The area between } 3430 \text { and } \\
3378 \mathrm{~cm}^{-1} \text { (AlOH structural } \\
\text { hydroxyl defects) is integrated } \\
\text { together (less conservative than } \\
\text { simple peak integrations) }\end{array}$ & Biró et al. (2017) \\
\hline 3315 & 3339 & 3272 & B & $\begin{array}{l}\text { AlOH structural hydroxyl de- } \\
\text { fects }\end{array}$ & $\begin{array}{l}\text { Kats (1962) } \\
\text { Stalder and Konzett (2012) }\end{array}$ \\
\hline 3200 & 3232 & 3153 & B & $\begin{array}{l}\text { Strongly bonding } \mathrm{H} \text { at the } \\
\text { quartz crystal surface or } \mathrm{Si}-\mathrm{O} \\
\text { bonds }\end{array}$ & $\begin{array}{l}\text { Kats (1962); Frigo et } \\
\text { al. (2016); Biró et al. (2016) } \\
\text { Stalder (2021) }\end{array}$ \\
\hline Total $\mathrm{OH}^{-}$region & 3502 & 3153 & B & $\begin{array}{l}\text { The whole hydroxyl region in- } \\
\text { tegrated completely with the } \\
\text { widest integration limits }\end{array}$ & - \\
\hline Epoxy & 3050 & 2800 & B & $\begin{array}{l}\text { Bands which are connected to } \\
\text { the residual glue }\end{array}$ & Biró et al. (2016) \\
\hline $\mathrm{SiO}_{2}$ overtone & 2110 & 1445 & A & $\begin{array}{l}\mathrm{SiO} \text { stretching bands (needed } \\
\text { for the thickness calculations) }\end{array}$ & Biró et al. (2016) \\
\hline
\end{tabular}

Table 3. The calculated structural hydroxyl and magmatic water content for each layer and the main statistical indicators.

\begin{tabular}{lrrrrrrr}
\hline Site/layer & $\begin{array}{r}\text { No. of } \\
\text { measured } \\
\text { phenocrysts }\end{array}$ & $\begin{array}{r}\text { Calculated structural } \\
\text { hydroxyl content } \\
(\text { wt ppm) }\end{array}$ & $\begin{array}{r}\text { Min } \\
(\text { wt ppm) }\end{array}$ & $\begin{array}{r}\text { Max } \\
(\text { wt ppm) }\end{array}$ & $\begin{array}{r}\text { Standard } \\
\text { deviation } \\
\text { (wt ppm) }\end{array}$ & $\begin{array}{r}\text { Relative standard } \\
\text { deviation } \\
(\%)\end{array}$ & $\begin{array}{r}\text { Calculated magmatic water } \\
\text { contents (using the new } \\
\text { partition coefficient) (wt } \%)\end{array}$ \\
\hline E & 30 & 9.2 & 6.8 & 15.1 & 1.7 & 18.0 & 6.0 \\
O & 30 & 9.4 & 7.0 & 14.1 & 1.6 & 17.2 & 6.1 \\
S & 23 & 9.2 & 6.4 & 12.8 & 1.6 & 17.3 & 6.0 \\
TD & 33 & 9.1 & 7.1 & 12.4 & 1.3 & 13.7 & 5.9 \\
BG & 33 & 9.1 & 7.1 & 12.0 & 1.3 & 13.8 & 5.9 \\
KH1 & 25 & 9.0 & 6.0 & 11.4 & 1.4 & 15.8 & 6.7 \\
KH2 & 25 & 10.2 & 1.4 & 15.7 & 2.6 & 25.6 & \\
\hline
\end{tabular}

tural hydroxyl contents is 1.4 to $15.7 \mathrm{wt}$ ppm, but both values are considered outliers (this is also the reason for the relatively high standard deviation).

\subsection{Transect and core-rim measurements}

The results of a representative transect measurement (a) and of two representative core-rim measurements $(b, c)$ are shown in Fig. 7. In general, no significant variability can be recognized along the transects. This also stands for the corerim measurements, where there is no significant and consistent difference in the structural hydroxyl content of the different parts of the measured crystals in the case of both $\mathrm{KH}$ and BFVA samples. Hence, possibly there is also no significant $\mathrm{H}^{+}$loss via diffusion, so all the sampled fallout deposits 
(BFVA and $\mathrm{KH}$ eruption alike) probably cooled down fast enough to avoid this post-emplacement diffusion loss.

\section{Discussion}

\subsection{Band assignment}

In all studied samples the hydroxyl region of the IR spectra is dominated by the $\mathrm{AlOH}$ triplet (at 3430, 3378, and $3315 \mathrm{~cm}^{-1}$, respectively) (Kats, 1962; Stalder and Konzett, 2012). These bands are related to coupled $\mathrm{Al}^{3+}+\mathrm{H}^{+}$substitution into the tetrahedral site replacing $\mathrm{Si}^{4+}$. In case of $\mathrm{E}, \mathrm{O}$, $\mathrm{S}, \mathrm{BG}$, and TD the band at $3197 \mathrm{~cm}^{-1}$ is very sharp and may be connected to the strongly bonding $\mathrm{H}^{+}$at the quartz crystal surface (Biró et al., 2016; Stalder, 2021) or can be assigned to $\mathrm{Si}-\mathrm{O}$ bonds (Kats, 1962). The minor but sharp band at $3478 \mathrm{~cm}^{-1}$ could be linked to the LiOH structural hydroxyl defects (Potrafke et al., 2020). The results of the measurements along transects and results of core-rim measurements showed that no intensity growth of the Li band (as described in the case of quartz from pyroclastic and granitic igneous bodies by Tollan et al., 2019, and Potrafke et al., 2020) or significant variations in the $\mathrm{AlOH}$ bands are visible in the spectra (Fig. 7; Tollan et al., 2019; Potrafke et al., 2020).

\subsection{Comparison with formerly published results}

The water content of natural quartz crystals from several rock types (sandstone, hydrothermal veins, granite) as well as of laboratory-grown crystals was in between 0 and a few hundred weight parts per million (Miyoshi et al., 2005; Müller and Koch-Müller, 2009; Stalder and Neuser, 2013; Stalder, 2014; Baron et al., 2015; Frigo et al., 2016; Stalder et al., 2017; Potrafke et al., 2019, 2020; Jollands et al., 2020b; Stalder, 2021). Hydroxyl content of volcanic quartz was investigated only in a few studies. The "water" content of quartz phenocrysts originating from a pyroclastic fallout layer of the Bishop Tuff is between 7 and $12 \mathrm{wt} \mathrm{ppm} \mathrm{(recalcu-}$ lated from Jollands et al., 2020b). Quartz crystals separated from rhyolites originating from Germany and Italy (Großer Inselsberg and Bolzano) showed 1.4 to $12 \mathrm{wt}$ ppm water content (Stalder and Neuser, 2013). In the BFVA volcanic quartz from a fallout horizon and several ignimbrite sequences was investigated recently (Biró et al., 2016, 2017). The results show a continuous decrease in the hydroxyl content from $\sim 13$ to $\sim 3 \mathrm{wt}$ ppm (or even in some cases close to zero) towards the middle part of the ignimbrite; thus they cannot be regarded as the original water content of the phenocrysts (Biró et al., 2017). Quartz phenocrysts from the fallout horizon right below the Mangó ignimbrite at the Eger site showed 12.1 wt ppm structural hydroxyl content (E-1 in Biró et al., 2017). This is in good agreement with the results obtained on quartz from the lowest part of the covering ignimbrite with 11.4 wt ppm (E-2 in Biró et al., 2017). The reason for the difference between this result (12.1 wt ppm) and our calculated structural hydroxyl content for quartz phenocrysts originating from this layer $(9.2 \mathrm{wt} \mathrm{ppm})$ is due to the different sample preparation methodology including using whole vs. fragmented crystals for the measurements (see Appendix A about single-crystal measurements).

There are several frequency distribution plots of the measured structural hydroxyl content of quartz phenocrysts (obtained using FTIR measurements with polarized light) originating mostly from granite bodies, metamorphic rocks, or detrital grains reported by Stalder and Neuser (2013), Stalder (2014) and Stalder et al. (2017). The present OH defect contents are close to the global average of $10 \mathrm{wt}$ ppm (Stalder and Neuser, 2013; Stalder, 2014; Stalder et al., 2017). The $0-10 \mathrm{wt}$ ppm range dominates these distribution plots (Fig. 7 of Stalder and Neuser, 2013, and Fig. 8 of Stalder et al., 2017), and the range we measured agrees well with these values. Quartz-bearing pyroclastic fallout deposits can cover large areas (up to a few tens of thousands of square kilometers; e.g., Wilson, 1993); hence volcanic quartz population originating from explosive eruptions (just like the sediments which formed after reworking of the fallout deposit) can also contribute to the crustal average. Vice versa, when a quartz population is found in an accumulated, reworked deposit with $\sim 10 \mathrm{wt}$ ppm characteristic structural hydroxyl content, volcanic origin can be assumed in the provenance analyses.

\subsection{Uniform $P, T$, and $x$ conditions in silicic magma reservoirs recorded by $\mathrm{OH}$ in quartz}

The structural hydroxyl contents of the quartz phenocryst populations are in a narrow range of 9.0-10.2 wt ppm in the correlated horizons of both BFVA and KH eruption samples (Figs. 5, 6 and Table 3). This narrow range in the average structural hydroxyl content could reflect similarities in the $P$, $T$, and $x$ (mainly $\mathrm{H}_{2} \mathrm{O}$ ) activity conditions in the magma storage system when the quartz phenocrysts equilibrated with the magma just before the significant degassing and/or eruption events.

Water contents of other NAMs (clinopyroxene, feldspar, etc.) can record conditions at different levels of the magmatic system, because they crystallize at different levels characterized by different $P, T$, and $x$ conditions (e.g., plagioclase; Hamada et al., 2011). For hydrogen a few minutes to hours are enough to attain equilibrium between the melt and the solid phase (crystals) due to its fast diffusion rates $\left(10^{-10}\right.$ to $10^{-14} \mathrm{~m}^{2} \mathrm{~s}^{-1}$ at $800^{\circ} \mathrm{C}$ in case of quartz and $10^{-12} \mathrm{~m}^{2} \mathrm{~s}^{-1}$ in the case of plagioclase; Hamada et al., 2013; Johnson and Rossman, 2013; Lloyd et al., 2016; Myers et al., 2018; Jollands et al., 2020b). Quartz usually crystallizes in the upper(most) part of the magmatic plumbing system over a geologically short period of time (a few hundred to few thousand years; Gualda et al., 2012; Matthews et al., 2012; Graeter et al., 2015; Tollan et al., 2019; Jollands et al., 2020b). The narrow range of the measured structural hydroxyl contents 

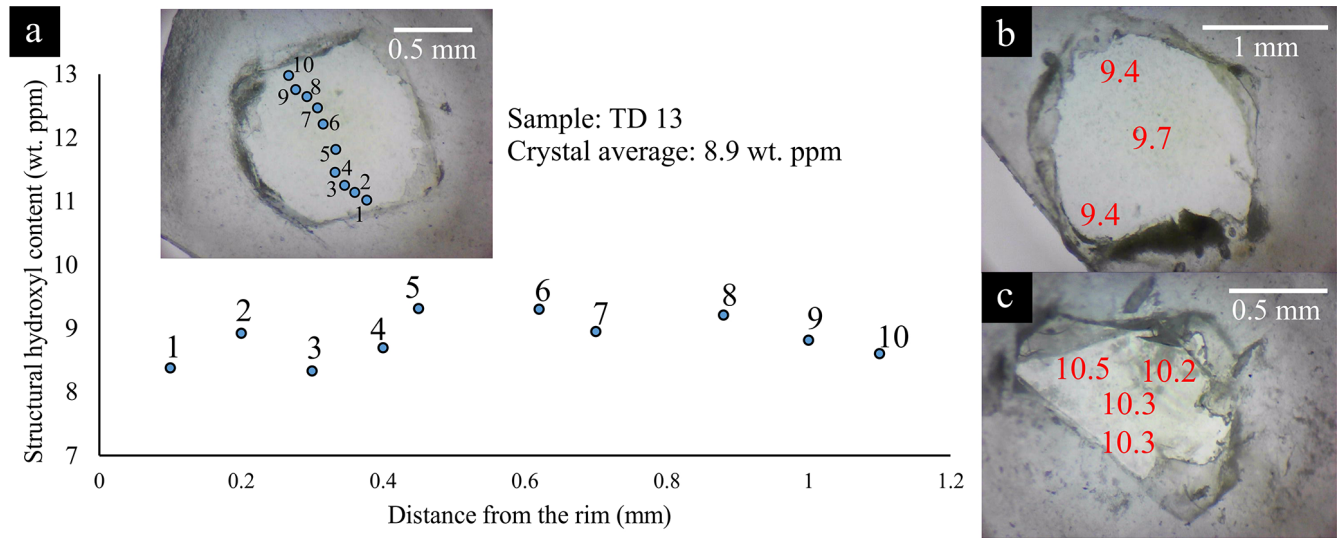

Figure 7. Example of structural hydroxyl concentration along a transect (a) and observed in core-rim relation (b, c). Note that no significant difference in structural hydroxyl content was observed along a transect nor in core vs. rim relation.

suggests a relatively uniform $P, T$, and $x$ environment and fast ascension (Myers et al., 2018). The amount of dehydration during or just before the eruption via $\mathrm{Li}-\mathrm{H}$ interdiffusion (e.g., Jollands et al., 2020b) was very minor based on the fact that (1) there is no strong zonation of $\mathrm{OH}$ towards the rims of the crystals and (2) the intergranular variability of obtained $\mathrm{OH}$ concentrations is rather small. If $\mathrm{Li}-\mathrm{H}$ interdiffusion was significant just before and during the eruption, various grain sizes should give various $\mathrm{OH}$ contents according to the grain size dependence of diffusion. During this latest stage of the crystallization there was enough time for re-equilibration of the quartz phenocrysts to eliminate any zoning or difference of the structural hydroxyl content in the crystal's structure (as seen in transect and core-rim measurements, Fig. 7).

Consequently, it can be inferred that the quartz phenocrysts (separated from pyroclastic fallout deposits) have almost the same structural hydroxyl content throughout the whole evolution of the felsic explosive volcanism in the BFVA. The two sampled layers can represent two large eruptive complexes (consist of several eruptions) of the BFVA (Fig. 2), besides several more eruption events (fed by one magma pocket; took up to several days or weeks) that occurred during the volcanism of the BFVA (Biró et al., 2020; Hencz et al., 2021a, b). This feature may be universal, since we measured identical structural hydroxyl contents in another much younger (essentially recent) volcanic field in New Zealand.

\subsection{Implications on the water content of the host melt}

Determining the dissolved water content of the silicate melt is essential to understand the dynamics of the volcanic eruptions (besides other magmatic volatiles, like $\mathrm{CO}_{2}, \mathrm{~S}, \mathrm{Cl}$, and F; Cashman, 2004) and to be able to predict the course of future eruptions based on the physical and chemical properties of the magma including its possible ascent rates (Lloyd et al., 2014; Myers et al., 2019; Popa et al., 2019; Tollan et al.,
2019; Allabar et al., 2020). Water content of NAMs can be in equilibrium with the dissolved water content of the melt in each level of the magma storage system, so their water content can be a good proxy to estimate the magmatic water content (Wallace, 2005; Portnyagin et al., 2008; Lloyd et al., 2013; Weis et al., 2015; Tollan et al., 2019; Jollands et al., 2020b). While FTIR is a useful tool to measure the water content of different NAMs as was demonstrated above, calculating magmatic water contents requires the application of a partition coefficient (i.e., the quantitative relation between water content of a given nominally anhydrous phase and the melt; Qin et al., 1992; Johnson and Rossman, 2003, 2013; Hauri et al., 2006; O'Leary et al., 2010; Lloyd et al., 2016).

Crystal and melt partition coefficients are available for several NAMs (e.g., clinopyroxene, plagioclase, olivine; Hauri et al., 2006; Grant et al., 2007; Hamada et al., 2013; Liu et al., 2015) but are not available for quartz. According to our best knowledge, only one single calculated partition coefficient is found in the published literature (i.e., $D^{\text {quartz/melt }}=$ 0.0001; Qin et al., 1992), where the partition coefficient was tentatively calculated based on applying a mathematical model which investigates the diffusive re-equilibration of $\mathrm{H}$ in melt inclusions with the host melt (Qin et al., 1992). In this partition coefficient the molecular water was also included (Qin et al., 1992; Myers et al., 2019). Using our new structural hydroxyl contents of quartz phenocrysts presented above ( $\sim 9.6 \mathrm{wt} \mathrm{ppm}$, which is the average of the calculated structural hydroxyl contents of KH eruption samples), it is possible to calculate the partition coefficient between quartz and silicate melts in the case of $\mathrm{KH}$ eruptions, because there are available magmatic water contents presented recently based on melt inclusion analyses $(6.1 \mathrm{wt} \%-6.5 \mathrm{wt} \%$ $\mathrm{H}_{2} \mathrm{O}$; Nairn et al., 2004). Using these data, the crystal-melt partition coefficient for quartz is $0.000157-0.000148$, thus 0.000153 on average. This partition coefficient is on the same order of magnitude as that of Qin et al. (1992), but according to our knowledge this is the first attempt to constrain 
$D_{\mathrm{H}_{2} \mathrm{O}}^{\text {quartz/melt }}$ based on coexistent natural mineral - silica glass pairs. The new calculated water contents (using this new partition coefficient) for the BFVA and $\mathrm{KH}$ eruption magmas is presented in Table 3.

All the measured samples originating from the fallout deposits of both BFVA (E-O-S and TD-BG) and KH eruptions (KH1 and KH2) represent the first fallout event of a largescale Plinian eruption. In the BFVA both sampled pyroclastic layers are mantling a paleosol (representing a dormant period in volcanism of a maximum of a few tens of kiloyears; Solleiro-Rebolledo et al., 2003). Similarly, sampling of the $\mathrm{KH}$ eruption fallout deposits was carried out from their basal part representing the first phase of the eruption (fed by highly differentiated T1 and T2 rhyolitic magma; Nairn et al., 2004). As was suggested earlier, the first phase of silicic eruptions used to be characterized with the highest $\mathrm{SiO}_{2}(76 \mathrm{wt} \%-$ $77 \mathrm{wt} \%$ ) content and with the largest magmatic $\mathrm{H}_{2} \mathrm{O}$ content (5 wt \%-6.5 wt \%; e.g., Blake, 1984; Anderson et al., 2000; Wallace et al., 2003; Nairn et al., 2004; Graeter et al., 2015). This can be explained by density-driven differentiation in silicic magma chambers: highly evolved/fractionated melts accumulate in the upper parts of a magma chamber, having the highest volatile content (including, of course, water contents, about $6 \mathrm{wt} \%-7 \mathrm{wt} \%$; Blake, 1984; Graeter et al., 2015). This water-rich melt part of the magma chamber is tapped first during eruption (Nairn et al., 2004).

\subsection{Further implications}

A study found that mafic arc magmas contain about $4 \mathrm{wt} \%$ dissolved water, based on investigations of melt inclusions trapped in volcanic phenocrysts (Plank et al., 2013). The identical water content of mafic arc magmas was explained by two things: (1) water contents are limited by the vapor saturation at the last storage level by degassing until ca. $4 \mathrm{wt} \%$ is reached, which seems to be optimal for the $P$ and $T$ conditions in arc settings, at the depth of magma stalling in the crust (Plank et al., 2013), and (2) mantle-source melting processes themselves limit the water content of the host melt, which maintains constant water content at mantle temperatures (Plank et al., 2013). The second scenario assumes a deeper magma chamber $(10-12 \mathrm{~km})$, where the melt stalls prior to the eruption, and the eruption is fed directly from that level (Plank et al., 2013). These models were developed only for mafic magmas based on the measured water content of olivine-hosted melt inclusions. In the case of silicic caldera-forming volcanism, however, the second scenario does not seem to be a realistic option (the uppermost magma chamber at $10 \mathrm{~km}$ depth), because in silicic systems the shallowest stalling level of magma is usually located at 2-7 km depth (Blundy and Cashman, 2001; Gualda et al., 2012, 2018; Graeter et al., 2015; Pamukçu et al., 2020). In the case of $\mathrm{KH}$ eruption $6.6 \mathrm{~km}$ depth was proposed (Nairn et al., 2004). As was mentioned before, the main crystallization episode of the quartz also takes place at such shal- low levels of the magmatic plumbing system (Graeter et al., 2015; Tollan et al., 2019; Jollands et al., 2020b; Pamukçu et al., 2020); thus we suggest a potential crustal water content "regulator" in the case of the BFVA (i.e., scenario 1 of Plank et al., 2013), limiting the water content of the melt to $\sim 5 \mathrm{wt} \%-7 \mathrm{wt} \%$. The melt was in equilibrium with the structural hydroxyl content of the crystallized quartz phenocrysts (to the measured $\sim 10 \mathrm{wt} \mathrm{ppm}$ ). This means that the physicochemical conditions ( $P-T$, oxygen fugacity, stress, etc.) may have been fairly uniform at the shallowest level of the magma plumbing system just before the eruption at several silicic magmatic provinces developed in an extension-dominated regime. A possible explanation may be the rheological features of the crust, which can be functioned as precursors for the depth and pressure conditions where magma will accumulate (Huber et al., 2019). As was suggested in recent studies (e.g., Huber et al., 2019), the optimal pressure conditions for the formation of a subvolcanic silicic magma chamber are in between 1.5 and $2.5 \mathrm{kbar}$, representing a $\sim 4$ to $7 \mathrm{~km}$ depth interval. This is in good agreement with the suggested depth for the KH eruption magma chamber $(6.6 \mathrm{~km})$ and may also suggest a similar depth for the BFVA eruptions. Interestingly, these depths are consistent with the depth where the water saturation occurs based on experimental calculations of Zhang et al. (2007). Thus, in this depth range large-scale bubble formation can start due to water saturation and exsolution, which can contribute significantly to triggering an eruption (Zhang et al., 2007). Consequently, the pressureand-depth range can be estimated for the equilibrium between quartz and melt based on our fairly uniform structural hydroxyl (and thus magmatic water) contents. Possibly, this crustal region was the last stall of the magma prior to the eruption.

Here we suggest that the "crustal regulator" of magma water content may be a general phenomenon in the Earth's upper crust in case of silicic magma plumbing systems (especially in an extensional back-arc setting such as the BFVA and TVZ), able to limit the explosive potential of the silicic magmas (as assumed by Plank et al., 2013). As Blake (1984) and Zhang et al. (2007) suggested, the oversaturation of water in the abovementioned pressure conditions can be a general worldwide phenomenon, which eliminates the possibility of further volatile enrichment of the magma, thus limiting the explosivity of the eruption (excluding other internal (e.g., $\mathrm{CO}_{2}$ content) or external (e.g., the presence of surface water driving phreatomagmatic eruptions) factors). To substantiate this hypothesis, more investigation is necessary in silicic volcanic fields, focused on the water content of the melt, whereas structural hydroxyl content of quartz phenocrysts could be a good proxy for that. 


\section{Conclusions}

The structural hydroxyl content of volcanic quartz phenocrysts was measured with unpolarized FTIR methodology. The quartz phenocrysts were separated from five pyroclastic fallout horizons from the Bükk Foreland Volcanic Area (northern Hungary) and from the first phase of the AD 1314 Kaharoa eruption (TVZ, New Zealand). The results of the study can be summarized as follows.

1. The measured volcanic quartz phenocrysts contain 9.3 $( \pm 1.7)$ wt ppm structural hydroxyl content on average.

2. Structural hydroxyl content of quartz does not depend on either the geographic or stratigraphic position of the hosting pyroclastic fallout horizon. Quartz phenocrysts from previously correlated pyroclastic fallout deposits show nearly the same structural hydroxyl content regardless of the thermal and/or pressure impact of the covering deposit.

3. The calculated structural hydroxyl contents fit well in the range of earlier published values from quartz phenocrysts derived from different geological environments (granitic bodies, metamorphic rocks, detrital grains), including volcanic quartz phenocrysts.

4. The calculated magmatic water contents (around $6 \mathrm{wt} \%$ $\mathrm{H}_{2} \mathrm{O}$ ) also fit well with earlier published water contents, especially in the case of the early explosive phase of Plinian eruptions of highly evolved felsic magma (e.g., the $\mathrm{KH}$ eruption).

5. The structural hydroxyl contents are nearly the same in quartz phenocrysts of pyroclastic fallout deposits in the BFVA. Hence, it can be assumed that $P, T$, and $x$ (mainly $\mathrm{H}_{2} \mathrm{O}$ ) activity could be similar in the uppermost (i.e., shallowest) storage level of the magmatic plumbing system, where quartz phenocrysts crystallized and chemically equilibrated with the melt. This geodynamic and petrologic environment thus constrained the structural hydroxyl content of the quartz phenocrysts, i.e., the water content of the host magma, which could have acted as an upper crustal-level regulator from a volcanic explosivity point of view.

6. The similarity of the average magmatic water content in the studied pyroclastic deposits is pointed out throughout the large-scale silicic caldera volcanism of both BFVA and TVZ (KH eruption), which could be a common feature in volcanic areas located in similar geodynamic environments. More occurrence areas of largescale silicic explosive volcanism worldwide need to be involved in future studies to prove this hypothesis. This could probably be the pressure-depth level at which the water saturation is achieved and water exsolution begins and triggers large-volume Plinian-type explosive eruptions.
The preliminary results underline the importance of measuring water contents of NAMs in fallout pyroclastic layers originating from extension-related silicic explosive eruptions in various volcanic fields.

\section{Appendix A: Single-crystal preparations}

To more accurately analyze the average unpolarized absorbance of our phenocrystal population, we crushed some quartz phenocrysts (from Eger site) manually in a mortar to be able to reproduce the methodology of Biró et al. (2017), who made the measurements on crushed (or fragmented) grains instead of separated euhedral or subhedral grains $(\mathrm{Ta}-$ ble 1; E-1 in Biró et al., 2017). The sample preparation methodology was almost the same as described above; however, at the end of the preparation the glue slab was dissolved with acetone, and the single phenocryst wafers were individually picked up and stored. The prepared phenocrysts were measured with the same unpolarized micro-FTIR methodology, but the single crystals were emplaced on a $\mathrm{CaF}$ supporting slide during the measurements.

The measurements resulted in higher structural hydroxyl content: $11.5( \pm 2.4) \mathrm{wt}$ ppm (Supplement File S3). The measured maximal indicative structural hydroxyl content is $15.5 \mathrm{wt} \mathrm{ppm}$. This could be the theoretical maximal indicative structural hydroxyl content of the quartz phenocrysts of the BFVA if the incident light travels parallel to the $c$ axis. In this case, it follows from the absorbance indicatrix theory of quartz (Sambridge et al., 2008; Kovács et al., 2008; Biró et al., 2017) that the average unpolarized absorbance should be $66 \%$ of this value, which is $10.3 \mathrm{wt} \mathrm{ppm}$. This agrees well with the empirically determined $11.5 \mathrm{wt}$ ppm. Hence, the reason for the difference between the results of this investigation and the measurements of Biró et al. (2017) is due to the different sample preparation methodology including the shape of the separated phenocrysts (fragmented vs. euhedral/subhedral crystals; see Sect. 3.2)

Data availability. Our datasets are available in the Supplement.

Supplement. The supplement related to this article is available online at: https://doi.org/10.5194/ejm-33-571-2021-supplement.

Author contributions. $\mathrm{MH}$ wrote and prepared the original draft, performed the sampling in the BFVA, sample preparation, measurements, and calculations. KN carried out the sampling in New Zealand. TB, IJK, AS, and KN carried out the conceptualization and reviewed and edited the manuscript. RS played a role in methodological specifications, investigations, and editing of the manuscript. ZsP made additional calculations for this methodology and reviewed the manuscript. ZoP and DK designed and concep- 
tualized the work. IJK and DK also provided the financial background.

Competing interests. Some authors are members of the editorial board of European Journal of Mineralogy. The peer-review process was guided by an independent editor, and the authors have also no other competing interests to declare.

Disclaimer. Publisher's note: Copernicus Publications remains neutral with regard to jurisdictional claims in published maps and institutional affiliations.

Special issue statement. This article is part of the special issue "Probing the Earth: reviews of $\mathrm{OH}$ groups in anhydrous and hydrous minerals". It is not associated with a conference.

Acknowledgements. Volcanological research of Tamás Biró was supported by the ÚNKP-20-4 New National Excellence Program of the Ministry of Innovation and Technology from the source of the National Research, Development and Innovation Found (ÚNKP20-4-II-ELTE-32). Volcanological research of Mátyás Hencz was supported by the ÚNKP-20-3 New National Excellence Program of the Ministry for Innovation and Technology from the source of the National Research, Development and Innovation Fund (ÚNKP20-3-II-ELTE-102). The research was supported by the European Union and the state of Hungary, co-financed by the European Regional Development Fund in the project GINOP-2.3.2.-15-201600009 "ICER”. Assistance of Szabolcs Kósik, Tamás Sági, and Sándor Józsa during the sampling; Dóra Kesjár during the FTIR measurements; and Zoltán Cseri in figure drawing is highly acknowledged.

We thank Mike Jollands and Hélène Balcone-Boissard for the in-depth review which improved the manuscript. We thank Etienne Balan for handling the manuscript.

Financial support. This research has been supported by the Hungarian Scientific Research Fund (grant nos. K115472, K128122, and K131894).

Review statement. This paper was edited by Etienne Balan and reviewed by Michael Jollands and Hélène Balcone-Boissard.

\section{References}

Aines, R. D. and Rossman, G. R.: Water in minerals? A peak in the infrared, J. Geophys. Res.-Earth, 89, 4059-4071, https://doi.org/10.1029/JB089iB06p04059, 1984.

Allabar, A., Salis Gross, E., and Nowak, M.: The effect of initial $\mathrm{H}_{2} \mathrm{O}$ concentration on decompression-induced phase separation and degassing of hydrous phonolitic melt, Contrib. Mineral. Petr., 175, 1-19, https://doi.org/10.1007/s00410-020-1659-2, 2020.
Anderson, A. T., Davis, A. M., and Lu, F.: Evolution of Bishop Tuff Rhyolitic Magma Based on Melt and Magnetite Inclusions and Zoned Phenocrysts, J. Petrol., 41/3, 449-473, https://doi.org/10.1093/petrology/41.3.449, 2000.

Balázs, A., Matenco, L., Magyar, I., Horváth, F., and Cloetingh, S. A. P. L.: The link between tectonics and sedimentation in back-arc basins: New genetic constraints from the analysis of the Pannonian Basin, Tectonics, 35, 1526-1559, https://doi.org/10.1002/2015tc004109, 2016.

Barker, S. J., Wilson, C. J. N., Illsley-Kemp, F., Leonard, G. S., Mestel, E. R. H., Mauriohooho, K., and Charlier, B. L. A.: Taupō: an overview of New Zealand's youngest supervolcano, New Zealand J. Geol. Geophys., 64, 1-27, https://doi.org/10.1080/00288306.2020.1792515, 2020.

Baron, M. A., Stalder, R., Konzett, J., and Hauzenberger, C. A.: $\mathrm{OH}$-point defects in quartz in B-and Li-bearing systems and their application to pegmatites, Phys. Chem. Miner., 42, 53-62, https://doi.org/10.1007/s00269-014-0699-4, 2015.

Barth, A., Newcombe, M., Plank, T., Gonnermann, H., Hajimirza, S., Soto, G., Saballos, A., and Hauri, E.: Magma decompression rate correlates with explosivity at basaltic volcanoes - constraints from water diffusion in olivine, J. Volcanol. Geoth. Res., 387, 106664, https://doi.org/10.1016/j.jvolgeores.2019.106664, 2019.

Biró, T., Kovács, I. J., Király, E., Falus, Gy., Karátson, D., Bendő, Z., Fancsik, T., and Sándorné, K. J.: Concentration of hydroxyl defects in quartz from various rhyolitic ignimbrite horizons: results from unpolarized micro-FTIR analyses on unoriented phenocryst fragments, Eur. J. Mineral., 28, 313-327, https://doi.org/10.1127/ejm/2016/0028-2515, 2016.

Biró, T., Kovács, I. J., Karátson, D., Stalder, R., Király, E., Falus, Gy., Fancsik, T., and Kovács, S. J.: Evidence for postdepositional diffusional loss of hydrogen in quartz phenocryst fragments within ignimbrites, Am. Mineral., 102, 1187-1201, https://doi.org/10.2138/am-2017-5861, 2017.

Biró, T., Hencz, M., Németh, K., Karátson, D., Márton, E., Szakács, A., Bradák, B., Szalai, Z., Pécskay, Z., and Kovács, I. J.: A Miocene Phreatoplinian eruption in the North-Eastern Pannonian Basin, Hungary: the Jató Member, J. Volcanol. Geoth. Res., 401, 1-21, https://doi.org/10.1016/j.jvolgeores.2020.106973, 2020.

Blake, S.: Volatile oversaturation during the evolution of silicic magma chambers as an eruption trigger, J. Geophys. Res., 89, 8237-8244, 1984.

Blundy, J. and Cashman, K.: Ascent driven crystallisation of dacite magmas at Mt St Helens, 1980-1986, Contrib. Mineral. Petr., 140, 631-650, https://doi.org/10.1007/s004100000219, 2001.

Briggs, R., Houghton, B., McWilliams, M., and Wilson, C.: 40Ar/39Ar ages of silicic volcanic rocks in the TaurangaKaimai area, New Zealand: Dating the transition between volcanism in the Coromandel Arc and the Taupo Volcanic Zone, New Zealand J. Geol. Geophys., 48, 459-469, https://doi.org/10.1080/00288306.2005.9515126, 2005.

Capaccioni, B., Coradossi, N., Harangi, R., Harangi, Sz., Karátson, D., Sarocchi, D., and Valentini, L.: Early Miocene pyroclastic rocks of the Bükkalja Ignimbrite Field (North Hungary) - A preliminary stratigraphic report, Acta Vulcanologica, 7, 119-124, 1995.

Cashman, K.: Volatile Controls on Magma Ascent and Eruption, Geoph. Monog. Series, 150, 109-124, https://doi.org/10.1029/150GM10, 2004. 
Cherniak, D. J. and Dimanov, A.: Diffusion in pyroxene, mica and amphibole, Rev. Miner. Geochem., 72, 641-690, https://doi.org/10.1515/9781501508394-015, 2010.

Cooper, G. F., Wilson, C. J. N., Millet, M. A., and Baker, J. A.: Generation and Rejuvenation of a Supervolcanic Magmatic System: a Case Study from Mangakino Volcanic Centre, New Zealand J. Petrol., 57, 1135-1170, https://doi.org/10.1093/petrology/egw035, 2016.

Csontos, L., Nagymarosy, A., and Horváth, F.: Tertiary evolution of the Intra-Carpathian area: A model, Tectonophysics, 208, 221-241, https://doi.org/10.1016/b978-0-444-89912-5.50017-x, 1992.

Deering, C., Bachmann, O., Dufek, J., and Gravley, D.: Rift-related transition from andesite to rhyolite volcanism in the Taupo Volcanic Zone (New Zealand) controlled by crystal-melt dynamics in mush zones with variable mineral assemblages, J. Petrol., 52, 2243-2263, https://doi.org/10.1093/petrology/egr046, 2011.

Dingwell, D. B.: Volcanic dilemma: Flow or blow?, Science, 273, 1054-1055, https://doi.org/10.1126/science.273.5278.1054, 1996.

Dixon, J. E. and Stolper, E. M.: An Experimental Study of Water and Carbon Dioxide Solubilities in Mid-Ocean Ridge Basaltic Liquids. Part II: Applications to Degassing, J. Petrol., 36, 16331646, 1995.

Ewart, A., Hildreth, W., and Carmichael, I. S. E.: Quaternary acid magma in New Zealand, Contrib. Mineral. Petr. 51, 1-27, 1975.

Frigo, C., Stalder, R., and Hauzenberger, C. A.: OH defects in quartz in granitic systems doped with spodumene, tourmaline and/or apatite: experimental investigations at 5-20 kbar Phys. Chem. Miner., 43, 717-729, https://doi.org/10.1007/s00269-016-08283, 2016.

Gleadow, A., Harrison, M., Kohn, B., Lugo-Zazueta, R., and Phillips, D.: The Fish Canyon Tuff: A new look at an old lowtemperature thermochronology standard, Earth Planet. Sc. Lett. 424, 95-108, https://doi.org/10.1016/j.epsl.2015.05.003, 2015.

Graeter, K. A., Beane, R. J., Deering, C. D., Gravley, D., and Bachmann, O.: Formation of rhyolite at the Okataina Volcanic Complex, New Zealand: New insights from analysis of quartz clusters in plutonic lithics, Am. Mineral., 100, 1778-1789, https://doi.org/10.2138/am-2015-5135, 2015.

Graham, I. H., Cole, J. W., Briggs, R. M., Gamble, J. A., and Smith, I. E. M.: Petrology and petrogenesis of volcanic rocks from the Taupo Volcanic Zone: A review, J. Volcanol. Geoth. Res., 68, 59-87, https://doi.org/10.1016/0377-0273(95)00008-I, 1995.

Grant, K. J., Kohn, S. C., and Brooker, R. A.: The partitioning of water between olivine, orthopyroxene and melt synthesised in the system albite-forsterite- $\mathrm{H}_{2} \mathrm{O}$, Earth Planet. Sc. Lett., 260, 227-241, https://doi.org/10.1016/j.epsl.2007.05.032, 2007.

Gravley, D. M., Deering, C. D., Leonard, G. S., and Rowland, J. V.: Ignimbrite flare-ups and their drivers: A New Zealand perspective, Earth Sci. Rev., 162, 65-82, https://doi.org/10.1016/j.earscirev.2016.09.007, 2016.

Gualda, G. A. R., Pamukçu, A. S., Ghiorso, M. S., Anderson Jr, A. T., Sutton, S. R., and Rivers, M. L.: Timescales of Quartz Crystallization and the Longevity of the Bishop Giant Magma Body, PLoS ONE, 7, e37492, https://doi.org/10.1371/journal.pone.0037492, 2012.

Gualda, G. A. R., Gravley, D. M., Connor, M., Hollmann, B., Pamukçu, A. S., Bégué, F., Ghiorso, M. S., and Deer- ing, C. D.: Climbing the crustal ladder: Magma storagedepth evolution during a volcanic flare-up, Sci. Adv., 4, 1-9, https://doi.org/10.1126/sciadv.aap7567, 2018.

Gualda, G. A. R, Gravley, D. M., Deering, C. D., and Ghiorso, M. S.: Magma extraction pressures and the architecture of volcanic plumbing systems, Earth Planet. Sc. Lett., 522, 118-124, https://doi.org/10.1016/j.epsl.2019.06.020, 2019.

Hamada, M., Kawamoto, T., Takahashi, E., and Fujii, T.: Polybaric degassing of island arc low-K tholeiitic basalt magma recorded by $\mathrm{OH}$ concentrations in Ca-rich plagioclase, Earth Planet. Sc. Lett., 308, 259-266, https://doi.org/10.1016/j.epsl.2011.06.005, 2011.

Hamada, M., Ushioda, M., Fujii, T., and Takahashi, E.: Hydrogen concentration in plagioclase as a hygrometer of arc basaltic melts: Approaches from melt inclusion analyses and hydrous melting experiments, Earth Planet. Sc. Lett., 365, 253-262, https://doi.org/10.1016/j.eps1.2013.01.026, 2013.

Harangi, S., Mason, P. R. D., and Lukács, R.: Correlation and petrogenesis of silicic pyroclastic rocks in the Northern Pannonian Basin, Eastern-Central Europe: In situ trace element data of glass shards and mineral chemical constraints, J. Volcanol. Geoth. Res., 143, 237-257, https://doi.org/10.1016/j.jvolgeores.2004.11.012, 2005.

Hauri, E. H., Gaetani, G. A., and Green, T. H.: Partitioning of water during melting of the Earth's upper mantle at $\mathrm{H}_{2} \mathrm{O}$ undersaturated conditions, Earth Planet. Sc. Lett., 248, 715-734, https://doi.org/10.1016/j.epsl.2006.06.014, 2006.

Hencz, M., Biró, T., Cseri, Z., Karátson, D., Márton, E., Németh, K., Szakács, A., Pécskay, Z., and Kovács, I. J.: A Lower Miocene pyroclastic-fall deposit from the Bükk Foreland Volcanic Area, Northern Hungary - clues for an eastward-located source, Geol. Carpath., 72, 26-47, https://doi.org/10.31577/geolcarp.72.1.3, 2021a.

Hencz, M., Biró, T., Cseri, Z., Németh, K., Szakács, A., Márton, E., Pécskay, Z., and Karátson, D.: Signs of complex eruption events at the Bükk Foreland (Northern-Hungary): the Kács Member, Extended abstract, Conference of Mining, Metallurgy and Geology 2021, Romania, 1-5, available at: https://ojs.emt.ro/index. php/bkf/article/view/513, 2021b (in Hungarian with English abstract).

Hildreth, W. and Moorbath, S.: Crustal contributions to arc magmatism in the Andes of Central Chile, Contrib. Mineral. Petr., 98, 455-489, https://doi.org/10.1007/bf00372365, 1988.

Hogg, A. G., Higham, T. F. G., Lowe, D. J., Palmer, J. G., Reimer, P. J., and Newnham, R. M.: A wiggle-match date for Polynesian settlement of New Zealand, Antiquity, 77, 116-125, https://doi.org/10.1017/s0003598x00061408, 2003.

Horváth, F.: Towards a mechanical model for the formation of the Pannonian basin, Tectonophysics, 226, 333-357, https://doi.org/10.1016/0040-1951(93)90126-5, 1993.

Horváth, F., Musitz, B., Balázs, A., Végh, A., Uhrin, A., Nádor, A., Koroknai, B., Pap, N., Tóth, T., and Wórum, G.: Evolution of the Pannonian Basin and its geothermal resources, Geothermics, 53, 328-352, https://doi.org/10.1016/j.geothermics.2014.07.009, 2015.

Huber, C., Townsend, M., Degruyter, W., and Bachmann, O.: Optimal depth of subvolcanic magma chamber growth controlled by volatiles and crust rheology, Nat. Geosci., 12, 762-768, https://doi.org/10.1038/s41561-019-0415-6, 2019. 
Johnson, E. A. E.: Water in nominally anhydrous crustal minerals: Speciation, concentration, and geologic significance, Rev. Mineral. Geochem., 62, 117-154, https://doi.org/10.1515/9781501509476-010, 2006.

Johnson, E. A. E. and Rossman, G. R.: The concentration and speciation of hydrogen in feldspars using FTIR and H-MAS-NMR-spectroscopy, Am. Mineral., 88, 901-911, https://doi.org/10.2138/am-2003-5-620, 2003.

Johnson, E. A. E. and Rossman, G. R.: The diffusion behavior of hydrogen in plagioclase feldspar at $800-1000^{\circ} \mathrm{C}$ : Implications for re-equilibration of hydroxyl in volcanic phenocrysts, Am. Mineral., 98, 1-10, https://doi.org/10.2138/am.2013.4521, 2013.

Jollands, M. C., Blanchard, M., and Balan, E.: Structure and theoretical infrared spectra of $\mathrm{OH}$ defects in quartz, Eur. J. Mineral., 32, 311-323, https://doi.org/10.5194/ejm-32-311-2020, 2020a.

Jollands, M. C., Ellis, B., Tollan, P. M. E., and Müntener, O.: An eruption chronometer based on experimentally determined $\mathrm{H}-\mathrm{Li}$ and $\mathrm{H}-\mathrm{Na}$ diffusion in quartz applied to the Bishop Tuff, Earth Planet. Sc. Lett., 551, 1-12, https://doi.org/10.1016/j.eps1.2020.116560, 2020b.

Kats, A.: Hydrogen in alpha quartz, Philips Res. Rep., 17, 133-279, 1962.

Kennedy, B. M., Holohan, E. P., Stix, J., Gravley, D. M., Davidson, J. R. J., and Cole, J. W.: Magma plumbing beneath collapse caldera volcanic systems, Earth-Sci. Rev., 177, 404-424, https://doi.org/10.1016/j.earscirev.2017.12.002, 2018.

Klemetti, E. W. and Cooper, K. M.: U-series crystal ages of plagioclase and zircon from the $1300 \mathrm{CE}$ Kaharoa eruption, New Zealand, Geochim. Cosmochim. Ac., 71, A491-A491, 2007.

Kósik, Sz.: Parasitic versus individual vents in the Central North Island, New Zealand: Small-volume volcanism associated with polygenetic volcanoes, $\mathrm{PhD}$ thesis, Massey University, Palmerston North, New Zealand, 350 pp., 2018.

Kósik, Sz., Németh, K., Lexa, J., and Procter, J. N.: Understanding the evolution of a small-volume silicic fissure eruption: Puketerata Volcanic Complex, Taupo Volcanic Zone, New Zealand, J. Volcanol. Geoth. Res., 383, 28-46, https://doi.org/10.1016/j.jvolgeores.2017.12.008, 2019.

Kósik, Sz., Bebbington, M., and Németh, K.: Spatio-temporal hazard estimation in the central silicic part of Taupo Volcanic Zone, New Zealand, based on small to medium volume eruptions, Bull. Volcanol., 82, 50, https://doi.org/10.1007/s00445-020-01392-6, 2020.

Kovács, I. and Szabó, Cs.: Middle Miocene volcanism in the vicinity of the Middle Hungarian zone: Evidence for an inherited enriched mantle source, J. Geodyn., 45, 1-15, https://doi.org/10.1016/j.jog.2007.06.002, 2008.

Kovács, I., Hermann, J., O’Neill, H. St. C., FitzGerald, J., Sambridge, M., and Horváth, G.: Quantitative IR spectroscopy with unpolarized light Part II: Empirical evidence and practical application, Am. Mineral., 93, 765-778, https://doi.org/10.2138/am.2008.2656, 2008.

Kovács, I., O’Neill, H. C., Hermann, J., and Hauri, E. H.: Site-specific infrared O-H absorption coefficients for water substitutions into olivine, Am. Mineral., 95, 292-299, https://doi.org/10.2138/am.2010.3313, 2010.

Kovács, I., Falus, Gy., Stuart, G., Hidas, K., Szabó, Cs., Flower, M. F. J., Hegedûs, E., Posgay, K., and Zilahi-Sebess, L.: Seismic anisotropy and deformation patterns in upper man- tle xenoliths from the central Carpathian-Pannonian region: Asthenospheric flow as a driving force for Cenozoic extension and extrusion?, Tectonophysics, 514-517, 168-179, https://doi.org/10.1016/j.tecto.2011.10.022, 2012.

Kronenberg, A. K., Kirby, S. H., Aines, R. D., and Rossman, G. R.: Solubility and Diffusional Uptake of Hydrogen in Quartz at High Pressures: Implications for Hydrolytic Weakening, J. Geophys. Res., 91, 12723-12744, https://doi.org/10.1029/JB091iB12p12723, 1986.

Leonard, G. S., Cole, J. W., Nairn, I. A., and Self, S.: Basalt triggering of the c. AD 1305 Kaharoa rhyolite eruption, Tarawera Volcanic Complex, New Zealand, J. Volcanol. Geoth. Res., 115, 461-486, https://doi.org/10.1016/s0377-0273(01)00326-2, 2002.

Liu, J., Xia, Q., Deloule, E., Chen, H., and Feng, M.: Recycled oceanic crust and marine sediment in the source of alkali basalts in Shandong, Eastern China: Evidence from magma water content and oxygen isotopes, J. Geophys. Res.-Sol. Ea., 120, 82818303, https://doi.org/10.1002/2015jb012476, 2015.

Lloyd, A. S., Plank, T., Ruprecht, P., Hauri, E. H., and Rose, W.: Volatile loss from melt inclusions in pyroclasts of differing sizes, Contrib. Mineral. Petr., 165, 129-153, https://doi.org/10.1007/s00410-012-0800-2, 2013.

Lloyd, A. S., Ruprecht, P., Hauri, E. H., Rose, W., Gonnermann, H. M., and Plank, T.: NanoSIMS results from olivinehosted melt embayments: Magma ascent rate during explosive basaltic eruptions, J. Volcanol. Geoth. Res., 283, 1-18, https://doi.org/10.1016/j.jvolgeores.2014.06.002, 2014.

Lloyd, A. S., Ferriss, E., Ruprecht, P., Hauri, E. H., Jicha, B. R., and Plank, T.: An Assessment of Clinopyroxene as a Recorder of Magmatic Water and Magma Ascent Rate, J. Petrol., 57, 18651886, https://doi.org/10.1093/petrology/egw058, 2016.

Lowe, D. K., McFadgen, B. G., Higham, T. F. G., Hogg, A. G., Frogatt, P. C., and Nairn, I. A.: Radiocarbon age of the Kaharoa tephra, a key marker for late Holocene stratigraphy and archaeology in New Zealand, The Holocene, 8, 499-507, https://doi.org/10.1191/095968398667037879, 1998.

Lukács, R., Harangi, Sz., Ntaflos, T., and Mason, P. R. D.: Silicate melt inclusions in the phenocrysts of the Szomolya Ignimbrite, Bükkalja Volcanic Field (Northern Hungary): Implications for magma chamber processes, Chem. Geol., 223, 46-67, https://doi.org/10.1016/j.chemgeo.2005.03.013, 2005.

Lukács, R., Harangi, Sz., Bachmann, O., Guillong, M., Danisik, M., Buret, Y, von Quadt, A., Dunkl, I., Fodor, L., Sliwinski, J., Soós, I., and Szepesi, J.: Zircon geochronology and geochemistry to constrain the youngest eruption events and magma evolution of the Mid-Miocene ignimbrite flare-up in the Pannonian Basin, eastern-central Europe, Contrib. Mineral. Petr., 170, 1-26, https://doi.org/10.1007/s00410-015-1206-8, 2015.

Lukács, R., Harangi, Sz., Guillong, M., Bachmann, O., Fodor, L., Buret, Y., Dunk1, I., Sliwinski, J., von Quadt, A., Peytcheva, I., and Zimmerer, M.: Early to Mid-Miocene syn-extensional massive silicic volcanism in the Pannonian Basin (EastCentral Europe): Eruption chronology, correlation potential and geodynamic implications, Earth Sci. Rev., 179, 1-19, https://doi.org/10.1016/j.earscirev.2018.02.005, 2018.

Madden-Nadeau, A. L. and Genge, M. J.: Fiamme degassing structures and their implications for the postemplacement temperatures and $\mathrm{H}_{2} \mathrm{O}$ contents of high- 
grade ignimbrites, J. Volcanol. Geoth. Res., 384, 251-262, https://doi.org/10.1016/j.jvolgeores.2019.08.003, 2019.

Márton, E. and Márton, P.: Large scale rotations in North Hungary during the Neogene as indicated by paleomagnetic data, in: Paleomagnetism and Tectonics of the Mediterranean Region, edited by: Morris, A. and Tarling, D. H., Geol. Soc. Spec. Publ., 105, 153-173, https://doi.org/10.1144/gsl.sp.1996.105.01.15, 1996.

Márton, E., Márton, P., and Zelenka, T.: Paleomagnetic correlation of Miocene pyroclastics of the Bükk Mts and their forelands, Central European Geology, 50, 47-57, https://doi.org/10.1556/ceugeol.50.2007.1.4, 2007.

Matthews, N. E., Pyle, D. M., Smith, V. C., Wilson, C. J. N., Huber, C., and van Hinsberg, V.: Quartz zoning and the preeruptive evolution of the $\sim 340$-ka Whakamaru magma systems, New Zealand, Contrib. Mineral. Petr., 163, 87-107, https://doi.org/10.1007/s00410-011-0660-1, 2012.

Miyoshi, N., Yamaguchi, Y., and Kuniaki, M.: Successive zoning of $\mathrm{Al}$ and $\mathrm{H}$ in hydrothermal vein quartz, Am. Mineral., 90, 310315, https://doi.org/10.2138/am.2005.1355, 2005.

Müller, A. and Koch-Müller, M.: Hydrogen speciation and trace element contents of igneous, hydrothermal and metamorphic quartz from Norway, Mineral. Mag., 73, 569-583, https://doi.org/10.1180/minmag.2009.073.4.569, 2009.

Myers, M. L., Wallace, P. J., Wilson, C. J. N., Watkins, J. M., and Liu, Y.: Ascent rates of rhyolitic magma at the onset of three caldera-forming eruptions, Am. Mineral., 103, 952-965, https://doi.org/10.2138/am-2018-6225, 2018.

Myers, M. L., Wallace, P. J., and Wilson, C. J. N.: Inferring magma ascent timescales and reconstructing conduit processes in explosive rhyolitic eruptions using diffusive losses of hydrogen from melt inclusions, J. Volcanol. Geoth. Res., 369, 95-112, https://doi.org/10.1016/j.jvolgeores.2018.11.009, 2019.

Nairn, I. A., Self, S., Cole, J. W., Leonard, G. S., and Scutter, C.: Distribution, stratigraphy, and history of proximal deposits from the $c$. AD 1305 Kaharoa eruptive episode at Tarawera Volcano, New Zealand, New Zeal. J. Geol. Geop., 44, 467-484, https://doi.org/10.1080/00288306.2001.9514950, 2001.

Nairn, I. A., Shane, P. R., Cole, J. W., Leonard, G. J., Self, S., and Pearson, N.: Rhyolitic magma processes of the $\sim$ AD 1314 Kaharoa eruption episode, Tarawera Volcano, New Zealand, J. Volcanol. Geoth. Res., 131, 265-294, https://doi.org/10.1016/s03770273(03)00381-0, 2004

Nairn, I. A., Hedenquist, J. W., Villamor, P., Berryman, K. R., and Shane, P. A.: The AD1315 Tarawera and Waiotapu eruptions, New Zealand: contemporaneous rhyolite and hydrothermal eruptions driven by an arrested basalt dike system?, Bull. Volcanol., 67, 186-193, https://doi.org/10.1007/s00445-004-0373-7, 2005.

Newnham, R. M., Lowe, D. J., McGlone, M. S., Wilmshurst, J. M., and Higham, T. F. G.: The Kaharoa Tephra as a critical datum for earliest human impact in northern New Zealand, J. Archeol. Sci., 25, 533-544, https://doi.org/10.1006/jasc.1997.0217, 1998.

Nicholls, I. A., Oba, T., and Conrad, W. K.: The nature of primary rhyolitic magmas involved in crustal evolution: Evidence from an experimental study of cummingtonite-bearing rhyolites, Taupo volcanic zone, New Zealand, in: The Taylor Colloquium; Origin and Evolution of Planetary Crusts, edited by: McLennan, S. M. and and Rudnick, R. L., Geochim. Cosmochim. Ac., 56, 955962, https://doi.org/10.1016/0016-7037(92)90039-1, 1992.
O'Leary, J. A., Gaetani, G. A., and Hauri, E. H.: The effect of tetrahedral $\mathrm{Al}^{3+}$ on the partitioning of water between clinopyroxene and silicate melt, Earth Planet. Sc. Lett., 297, 111-120, https://doi.org/10.1016/j.eps1.2010.06.011, 2010.

Pamukçu, A. S., Wright, K. A., Gualda, G. A. R., and Gravley, D.: Magma residence and eruption at the Taupo Volcanic Center (Taupo Volcanic Zone, New Zealand): insights from rhyolite-MELTS geobarometry, diffusion chronometry, and crystal textures, Contrib. Mineral. Petr., 175, 1-27, https://doi.org/10.1007/s00410-020-01684-2, 2020.

Plank, T., Kelley, K. A., Zimmer, M. M., Hauri, E .H., and Wallace, P. J.: Why do mafic arc magmas contain $\sim 4 \mathrm{wt} \%$ water on average?, Earth Planet. Sc. Lett., 364, 168-179, https://doi.org/10.1016/j.epsl.2012.11.044, 2013.

Pécskay, Z., Lexa, J., Szakács, A., Seghedi, I., Balogh, K., Konečný, V., Zelenka, T., Kovacs, M., Tóka, T., Fülöp, A., Márton, E., Panaiotu, C., and Cvetkovic, V.: Geochronology of Neogene magmatism in the Carpathian arc and intra-Carpathian area, Geol. Carpath., 57, 511-530, 2006.

Pensa, A., Porreca, M., Corrado, S., Giordano, G., and Cas, R.: Calibrating the pTRM and charcoal reflectance (Ro\%) methods to determine the emplacement temperature of ignimbrites: Fogo A sequence, Sao Miguel, Azores, Portugal, as a case study, Bull. Volcanol., 77, 18, https://doi.org/10.1007/s00445015-0904-4, 2015.

Petrik, A., Fodor, L., Bereczki, L., Klembala, Z., Lukács, R., Baranyi, V., Beke, B., and Harangi, Sz.: Variation in style of magmatism and emplacement mechanism induced by changes in basin environments and stress fields (Pannonian Basin, Central Europe), Basin Res., 31, 380-404, https://doi.org/10.1111/bre.12326, 2019.

Póka, T., Zelenka, T., Szakács, A., Seghedi, I., Nagy, G., and Simonits, A.: Petrology and geochemistry of the Miocene acidic explosive volcanism of the Bükk Foreland, Pannonian Basin, Hungary, Acta Geologica Hungarica, 41, 437-466, 1998.

Popa, R.-G., Bachmann, O., Ellis, B. E., Degruyter, W., Tollan, P., and Kyriakopoulos, K.: A connection between magma chamber processes and eruptive styles revealed at NisyrosYali volcano (Greece), J. Volcanol. Geoth. Res., 387, 106666 , https://doi.org/10.1016/j.jvolgeores.2019.106666, 2019.

Popa, R.-G., Dietrich, V. J., and Bachmann, O.: Effusive-explosive transitions of water-undersaturated magmas. The case study of Methana Volcano, South Aegean Arc, J. Volcanol. Geoth. Res., 399, 106884, https://doi.org/10.1016/j.jvolgeores.2020.106884, 2020.

Popa, R.-G., Tollan, P., Bachmann, O., Schenker, V., Ellis, B., and Allaz, J. M.: Water exsolution in the magma chamber favors effusive eruptions: Application of Cl-F partitioning behavior at the Nisyros-Yali volcanic area, Chem. Geol., 570, 120170, https://doi.org/10.1016/j.chemgeo.2021.120170, 2021.

Portnyagin, M., Almeev, R., Matveev, S., and Holtz, F.: Experimental evidence for rapid water exchange between melt inclusions in olivine and host magma, Earth Planet. Sc. Lett., 272, 541-552, https://doi.org/10.1016/j.epsl.2008.05.020, 2008.

Potrafke, A., Stalder, R., Schmidt, B. C., and Ludwig, T.: OH defect contents in quartz in a granitic system at $1-5 \mathrm{kbar}$, Contrib. Mineral. Petr., 174, 98, https://doi.org/10.1007/s00410-019-1632-0, 2019. 
Potrafke, A., Breiter, K., Ludwig, T., Neuser, R. D., and Stalder, R.: Variations of $\mathrm{OH}$ defects and chemical impurities in natural quartz within igneous bodies, Phys. Chem. Miner., 47, 24, https://doi.org/10.1007/s00269-020-01091-w, 2020.

Qin, Z., Lu, F., and Anderson, A. T.: Diffusive reequilibration of melt and fluid inclusions, Am. Mineral., 77, 565-576, 1992.

Reynes, J., Jollands, M., Herman, J., and Ireland, T.: Experimental constraints on hydrogen diffusion in garnet, Contrib. Mineral. Petr., 173, 69, https://doi.org/10.1007/s00410-018-1492-z, 2018.

Robertson, D. J.: Paleomagnetism of c. AD 1314 Kaharoa rhyolite and the New Zealand paleosecular variation master curve NZPSV2007, New Zealand J. Geol. Geophys., 50, 39-50, https://doi.org/10.1080/00288300709509819, 2007.

Ronov, A. B. and Yaroshevski, A. A.: Chemical composition of the Earth's crust, in: The Earth's crust and upper mantle, edited by: Hart, P. J., American Geophysical Union, Washington, 37-57, https://doi.org/10.1029/gm013p0037, 1969.

Sahetapy-Engel, S., Self, S., Carey, R. J., and Nairn, I. A.: Deposition and generation of multiple widespread fall units from the $c$. AD 1314 Kaharoa rhyolitic eruption, Tarawera, New Zealand, Bull. Volcanol., 76, 1-28, https://doi.org/10.1007/s00445-0140836-4, 2014.

Sambridge, M., FitzGerald, J., Kovács, I., O’Neill, H. St. C., and Hermann, J.: Quantitative absorbance spectroscopy with unpolarized light: Part I. Physical and mathematical development, Am. Mineral., 93, 751-764, https://doi.org/10.2138/am.2008.2657, 2008.

Schréter, Z.: Geological properties of the southeastern side of the Bükk Mountains, Annual report of the Geological Institute of Hungary 1933-35, 511-532, 1939 (in Hungarian).

Solleiro-Rebolledo, E., Sedov, S., Gama-Castro, J., Flores-Román, D., and Ecamilla-Sarabia, G.: Paleosol-sedimentary sequences of the Glacis de Buenavista, Central Mexico: interaction of Late Quaternary pedogenesis and volcanic sedimentation, Quatern. Int., 106-107, 185-201, https://doi.org/10.1016/s10406182(02)00172-6, 2003.

Sparks, R. S. J.: The dynamics of the bubble formation and growth in magmas: a review and analysis, J. Volcanol. Geoth. Res., 3, 1-37, https://doi.org/10.1016/0377-0273(78)90002-1, 1978.

Stagpoole, V., Miller, C., Tontini, F. C., Brakenrig, T., and Macdonald, N.: A two million-year history of rifting and caldera volcanism imprinted in new gravity anomaly compilation of the Taupo Volcanic Zone, New Zealand, New Zeal. J. Geol. Geop., 64, 358371, https://doi.org/10.1080/00288306.2020.1848882, 2020.

Stalder, R.: $\mathrm{OH}^{-}$defect content in detrital quartz grains as an archive for crystallisation conditions, Sediment. Geol., 307, 16, https://doi.org/10.1016/j.sedgeo.2014.04.002, 2014.

Stalder, R.: OH point defects in quartz - a review, Eur. J. Mineral., 33, 145-163, https://doi.org/10.5194/ejm-33-145-2021, 2021.

Stalder, R. and Konzett, J.: $\mathrm{OH}$ defects in quartz in the system quartz-albite-water and granite-water between 5 and 25 kbar, Phys. Chem. Miner., 39, 817-827, https://doi.org/10.1007/s00269-012-0537-5, 2012.

Stalder, R. and Neuser, D. R.: $\mathrm{OH}^{-}$defects in detrital quartz grains: Potential for application as tool for provenance analysis and overview over crustal average, Sediment. Geol., 294, 118-126, https://doi.org/10.1016/j.sedgeo.2013.05.013, 2013.

Stalder, R., Potrafke, A., Billström, K., Skogby, H., Meinhold, G., Gögele, C., and Berberich, T.: $\mathrm{OH}$ defects in quartz as monitor for igneous, metamorphic, and sedimentary processes, Am. Mineral., 102, 1832-1842, https://doi.org/10.2138/am-2017-6107, 2017.

Stenina, N. G.: Water-related defects in quartz, Bull. Geosci., 79, 251-268, 2004.

Szabó, Cs., Harangi, Sz., and Csontos, L.: Review of Neogene and Quaternary volcanism of the Carpathian-Pannonian Region, Tectonophysics, 208, 243-256, https://doi.org/10.1016/00401951(92)90347-9, 1992.

Szakács, A., Márton, E., Póka, T., Zelenka, T., Pécskay, Z., and Seghedi, I.: Miocene acidic explosive volcanism in the Bükk Foreland, Hungary: Identifying eruptive sequences and searching for source locations, Acta Geologica Hungarica, 41, 413-435, 1998.

Thomas, S-M., Koch-Müller, M., Reichart, P., Rhede, D., Thomas, R., and Wirth, R.: IR calibrations for water determination in olivine, $\mathrm{r}-\mathrm{GeO} 2$ and $\mathrm{SiO} 2$ polymorphs, Phis. Chem. Mineral., 36, 489-509, https://doi.org/10.1007/s00269-009-0295-1, 2009.

Tollan, P., Ellis, B., Troch, J., and Neukampf, J.: Assessing magmatic volatile equilibria through FTIR spectroscopy of unexposed melt inclusions and their host quartz: a new technique and application to the Mesa Falls Tuff, Yellowstone, Contrib. Mineral. Petr., 174, 1-24, https://doi.org/10.1007/s00410-019-1561y, 2019.

Turner, M., Turner, S., Mironov, N., Portnyagin, M., and Hoernle, $\mathrm{K}$.: Can magmatic water contents be estimated from clinopyroxene phenocrysts in some lavas? A case study with implications for the origin of the Azores Islands, Chem. Geol., 466, 436-445, https://doi.org/10.1016/j.chemgeo.2017.06.032, 2017.

Wallace, P. J.: Volatiles in subduction zone magmas: concentrations and fluxes based on melt inclusion and volcanic gas data, J. Volcanol. Geoth. Res., 140, 217-240, https://doi.org/10.1016/j.jvolgeores.2004.07.023, 2005.

Wallace, P. J., Dufek, J., Anderson, A. T., and Zhang, Y.: Cooling rates of Plinian-fall and pyroclastic-flow deposits in the Bishop Tuff: inferences from water speciation in quartz-hosted glass inclusions, Bull. Volcanol., 65, 105-123, https://doi.org/10.1007/s00445-002-0247-9, 2003.

Weis, F. A., Skogby, H., Troll, V. R., Deegan, F. M., and Dahren, B.: Magmatic water contents determined through clinopyroxene: Examples from the Western Canary Islands, Spain, Geochem. Geophy. Geosy., 16, 2127-2146, https://doi.org/10.1002/2015gc005800, 2015.

Wilson, C. J. N.: Stratigraphy, chronology, styles and dynamics of late Quaternary eruptions from Taupo volcano, New Zealand, Philos. T. Roy. Soc. A., 343, 205-306, https://doi.org/10.1098/rsta.1993.0050, 1993.

Wilson, C. J. N.: The 26.5 ka Oruanui eruption, New Zealand: an introduction and overview, J. Volcanol. Geoth. Res., 112, 133174, https://doi.org/10.1016/s0377-0273(01)00239-6, 2001.

Wilson, C. J. N. and Rowland, J. V.: The volcanic, magmatic and tectonic setting of the Taupo Volcanic Zone, New Zealand, reviewed from a geothermal perspective, Geothermics, 59, 168187, https://doi.org/10.1016/j.geothermics.2015.06.013, 2016.

Wilson, C. J. N. and Walker, G. P. L.: The Taupo eruption, New Zealand, I. General aspects, Phil. Trans. R. Soc. Lond. A., 314, 199-228, 1985.

Wilson, C. J. N., Houghton, B. F., McWilliams, M. O., Lanphere, M. A., Weaver, S. D., and Briggs, R. M.: Volcanic and struc- 
tural evolution of Taupo Volcanic Zone, New Zealand: a review, J. Volcanol. Geoth. Res., 68, 1-28, 1995.

Wright, I. C.: Shallow structure and active tectonism of an offshore continental back-arc spreading system: the Taupo Volcanic Zone, New Zealand, Mar. Geol., 103, 287-309, https://doi.org/10.1016/0025-3227(92)90021-9, 1992.
Zhang, Y., Xu, Z., Zhu, M., and Wang, H.: Silicate melt properties and volcanic eruptions, Rev. Geophys., 45, RG4004, https://doi.org/10.1029/2006RG000216, 2007.

Zhang, Y., Ni, H., and Chen, Y.: Diffusion data in silicate melts, Rev. Miner. Geochem., 72, 311-408, 2010. 